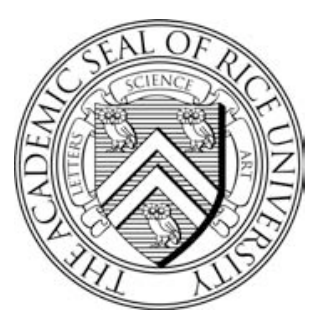

The James A. Baker I II Institute for Public Policy RICE UNIVERSITY

\title{
What Holds Back the Second Generation? THE INTERGENERATIONAL TRANSMISSION OF LANGUAGE Human CAPITAl AMONG IMMIGRANTS
}

\author{
BY \\ HOYT BlEAKLEY, PH.D. \\ Assistant Professor, Graduate SChOOl of Business \\ UNIVERSITY OF CHICAGO \\ AND \\ Aimee Chin, Ph.D. \\ Assistant Professor, Department of ECONOMics \\ UNIVERSITY OF HOUSTON
}

August 2007 


\section{What Holds Back the Second Generation?}

THESE PAPERS WERE WRITTEN BY A RESEARCHER (OR RESEARCHERS) WHO PARTICIPATED IN A BAKER INSTITUTE RESEARCH PROJECT. WHEREVER FEASIBLE, THESE PAPERS ARE REVIEWED BY OUTSIDE EXPERTS BEFORE THEY ARE RELEASED. HOWEVER, THE RESEARCH AND VIEWS EXPRESSED IN THESE PAPERS ARE THOSE OF THE INDIVIDUAL RESEARCHER(S), AND DO NOT NECESSARILY REPRESENT THE VIEWS OF THE JAMES A. BAKER III INSTITUTE FOR PUbliC POLICY.

The authors thank Frank Bean, Eli Berman, Nora Gordon, Gordon Hanson, Chinhui Juhn, Peter Mieszkowski, Stephen Trejo and participants at the Fall

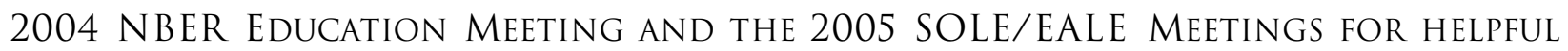
COMMENTS AND DISCUSSION. FINANCIAL SUPPORT FROM THE NATIONAL INSTITUTE OF Child Health and Human Development (R03-HD051562), Rice University's Baker InSTITUTE, UNIVERSITY OF CALIFORNiA'S LingUisTiC MINORITY RESEARCH INSTITUTE AND UNIVERSITY OF HOUSTON'S GEAR PROGRAM IS GRATEFULLY ACKNOWLEDGED.

(C) 2007 by the James A. Baker III Institute for PUblic POliCy of Rice University

THIS MATERIAL MAY BE QUOTED OR REPRODUCED WITHOUT PRIOR PERMISSION, PROVIDED APPROPRIATE CREDIT IS GIVEN TO THE AUTHOR AND

THE JAMES A. BAKER III INSTITUTE FOR PUBLIC POLICY. 


\title{
What Holds Back the Second Generation?
}

\begin{abstract}
In 2000 Census microdata, various outcomes of second-generation immigrants are related to their parents' age at arrival in the United States, and in particular whether that age fell within the "critical period" of language acquisition. We interpret this as an effect of the parents' Englishlanguage skills and construct an instrumental variable for parental English proficiency. Estimates of the effect of parents' English-speaking proficiency using two-stage least squares yield significant, positive results for children's English-speaking proficiency and preschool attendance, and significant, negative results for dropping out of high school and being below
\end{abstract} age-appropriate grade. (JEL J13, J24, J62)

\section{Introduction}

The children of immigrants lag behind the children of natives in educational and economic achievement. ${ }^{1}$ In a nation of immigrants, why this is the case becomes a question of major importance. Of particular concern are the disadvantages that the second generation inherits from its immigrant parents.

The gap between the second generation and other natives appears to be linked to Englishlanguage proficiency. More than 8 percent of students enrolled in U.S. public schools are classified as limited English proficient (LEP), of which three-quarters are Hispanic. ${ }^{2}$ Surprisingly, only half of these LEP students are actually foreign-born. The rest are U.S.-born, mostly the children of immigrants. Evidently, growing up and attending school in the United States are not sufficient in order to develop English-language proficiency. In this setting, parental English-language skills might have an important role in the educational (and therefore economic) assimilation of their children. And yet we are not aware of studies that rigorously examine the effect of immigrant parents' English-language skills on children's outcomes. ${ }^{3}$ (We review related

1. See recent work by Card, DiNardo and Estes (2000), Grogger and Trejo (2002), and Smith (2003).

2. Zehler et al. (2003), using data provided by school districts, estimates 4.0 million LEP students in grades K-12 in US public schools in the 2001-02 school year. Different school districts have different standards for classifying a student as LEP, but the commonality is that students classified as LEP are deemed to have inadequate English skills. 3. One possible exception is Leon (2003), which estimates the effects of ethnic capital and parental capital on children's school enrollment using 1910 and 1920 Census data. Parental capital is measured as the ability to read 


\section{What Holds Back the Second Generation?}

literature in Section II.A.)

A considerable challenge to estimating the causal effect of parental English-language skills on children's outcomes is the endogeneity of the parental language skills. Parental English-language skills are correlated with many other variables that also affect child outcomes, such as parental ability, income, education, and cultural attitudes. Additionally, reverse causality is possible. For example, as children become more English-proficient, they teach their parents English or force their parents to learn English. For these reasons, ordinary least squares (OLS) regressions of a child outcome on parental language skills may not estimate the causal effect.

In this study, we identify the causal effect of parental English-language skills by taking advantage of the psychobiological phenomenon that younger children learn languages more easily than older children and adults. We show in Section III.A that there is indeed a strong association between immigrants' age at arrival in the United States and their English-language skills. This leads us to use an instrumental variable for parental English derived from immigrant parents' age at arrival. One complication is that age at arrival probably affects immigrants through channels other than language, such as through better knowledge of American culture and institutions. We therefore use immigrants from English-speaking countries to control for nonlanguage-related age-at-arrival effects. The result is an instrumental-variables strategy using age at arrival interacted with a dummy for non-English-speaking country as the exclusion restriction.

We implement our instrumental-variables strategy using individual-level data from the 2000 U.S. Census. The data are described in Section II.B. In Section III.B, we find that immigrant parents' English-speaking proficiency has a significant positive effect on U.S.-born children's Englishspeaking proficiency while the children are young, but ceases to matter by the time they reach middle school. Since children with limited-English-proficient parents enter school with poorer English-language skills on average, a logical question to ask is whether this early deficiency has longer-term consequences. We estimate the effect of parental English on children's educational

and write in any language interacted with the ability to speak English. The coefficient of this variable should therefore be interpreted as some mix of the effect of parental education and English-language skills. In addition, since our first working paper version was issued (Bleakley and Chin 2004b), we have become aware of Casey and Dustmann (2005), which examines the effect of parental language skills using German panel data. 
outcomes in Section IV. We find that children with limited-English-proficient parents are more likely to drop out of high school, be below their age-appropriate grade, and not attend preschool. In Section V, we perform robustness checks and examine mechanisms for the effect of parental English on children's outcomes. Section VI concludes.

\section{Background}

\section{A. Related Literature}

We are not aware of studies that estimate the effect of immigrant parents' English-language skills on children's language and educational outcomes, let alone attempt to isolate the causal effect. $^{4}$ A number of studies have examined the determinants of language and educational outcomes of the children of immigrants; parental English-language skills are not among the many individual, family, school, and social capital characteristics considered in their regression models. They consistently find that family income and parental education are among the most important determinants of children's academic success (for example, Portes and MacLeod (1999); Card, DiNardo, and Estes (2000); Hirschman (2001); and Grogger and Trejo (2002)). Some of these studies include children's English-language proficiency as an explanatory variable, and this tends to have large effects (for example, Portes and MacLeod (1999) and Bleakley and Chin (2004a)). A few studies also include a home language background measure as an explanatory variable (for example, Grogger and Trejo (2002) and Glick and White (2003)). The measures of home language background are usually based on the language the child uses at home. $^{5}$ It is debatable whether they measure parental English-language skills, since which language is used and which languages are known could be different things. ${ }^{6}$

Some studies have examined the determinants of language outcomes of the children of immigrants. They tend to be more concerned with the maintenance of the heritage language than the acquisition of English, and leave unanswered the effect of parental English-language skills on

4. See previous footnote for exceptions.

5. For example, to measure home language environment, Grogger and Trejo use a dummy for child speaks language other than English with parents, and Glick and White use four dummies characterizing language use at home: only English, only non-English language, both with English dominating and both with non-English language dominating. 6. A child may speak to his/her parent in a language other than English for a variety of reasons: (1) he himself/she herself does not speak English; (2) his/her parents do not understand English; or (3) the parents understand English but want to enforce using the heritage language at home. 


\section{What Holds Back the Second Generation?}

child's English-language skills (for example, Portes and Hao (1998)).

Other studies on the language outcomes of childhood immigrants tend to be more descriptive. For each immigrant generation (the immigrants themselves (1st), their U.S.-born children (2nd), and their US-born grandchildren (3rd)), these studies might report the proportion who use the heritage language or English (for example, Hernandez and Charney (1998) and Suro and Passel (2003)). These studies help us understand how quickly members of a certain ethnicity or nationality adopt English (often at the expense of the heritage language). However, they tend to leave open the question of what channels mediate this growth of English use generation by generation. Is English spreading through the parent-child link per se, because the entire ethnic community is adopting English which affects the children in that community irrespective of their parents, or because of other variables that are changing generation by generation?

Although there has not been research on the effect of parental English-language skills on the children of immigrants, there is good reason to believe it is an important mechanism for their assimilation into U.S. society. Research in child language development has shown that parental literacy skills and practices have measurable effects on their children's cognitive abilities. For example, when parents read to their children, use a larger vocabulary, or discuss more complex ideas, children's language and educational outcomes improve (for example, Hart and Risley (1995) and Farkas and Beron (2004)). The type of parental language skills considered in these studies is more subtle than the type considered in the present paper. One would expect whether a parent knows a language at all would have more pronounced effects on children than, say, whether a parent knows 8,000 English words or 10,000.

Our paper is among the first to estimate the effect of parental English-language skills on the language and educational outcomes of the children of immigrants. A further contribution is the use of an instrumental-variables (IV) strategy to identify the causal effect of parental Englishlanguage skills. Several recent studies have used IV strategies to estimate the intergenerational effects of parental education, including Currie and Moretti (2003), Black, Devereux, and Salvanes (2005), and Oreopoulos, Page, and Stevens (2006). The tenor of these studies is that parents and children share many factors, the researcher can rarely control for all these factors, 


\section{What Holds Back the Second Generation?}

and consequently OLS estimates of the effects of parental human capital on child outcomes are likely to be biased. IV strategies are used to address the endogeneity problem.

\section{B. Data and Descriptive Statistics}

We implement our empirical strategy using individual-level data from the 2000 U.S. Census of Population and Housing. ${ }^{7}$ The 2000 Census offers measures of English-language skills for individuals age 5 and above. ${ }^{8}$ These measures are self-reported, and many researchers studying the relationship between language and earnings have used them. ${ }^{9}$ Another attractive feature of the 2000 Census is that for individuals born outside the 50 states and the District of Columbia, there is also information on exact year of arrival in the United States; previous censuses provided year of arrival in multi-year intervals, making our IV strategy less precise. A well-known disadvantage of the Census data, though, is the lack of rich measures of child school performance. For the children we study, who are at risk for dropping out of high school, several meaningful measures of educational outcomes can be gleaned from the 2000 Census. Using the measures of educational attainment, current school attendance, current grade attending, and age, we construct measures of school attendance and grade-for-age for the very young children (aged 3-7) and older teens (aged 15-17). ${ }^{10}$ For the very young children, we look at probability of attending school, probability that a 6-year-old is in kindergarten or higher, and the probability that a 7-year-old is in first grade or higher. For the older teens, we examine the probability of dropping out of high school and probability of being below the age-appropriate grade. ${ }^{11}$

7. Specifically, we combine the 1-percent and 5-percent Public Use Microdata Sample files downloaded from the Integrated Public Use Microdata Series (IPUMS) website (Ruggles et al. (2004)).

8. The Census question based on which the English-ability measures in this paper are constructed is: "How well does this person speak English?" with the four possible responses "very well," "well," "not well," and "not at all." This question is only asked of individuals responding affirmatively to "Does this person speak a language other than English at home?" We have coded individuals who do not answer "Yes" to speaking another language as speaking English "very well." We form an ordinal measure of English-speaking ability as follows: $0=$ speaks English not at all, 1 = speaks English not well, 2 = speaks English well, and 3 = speaks English very well.

9. Kominski (1989) reports that the Census measure of English-speaking ability is highly correlated with standardized tests of English-language skills and functional measures of English-language skills.

10. For 8- to 14-year-olds, there is little variation in the school attendance rate (it is around 99 percent), which is not surprising given the compulsory schooling laws. Moreover, because grade of school attendance and educational attainment at lower levels are measured in broad categories in the 2000 Census (attendance in grades 1-12 is measured in three categories, 1-4, 5-8, and 9-12; grades 1-12 attainment is better-1-4, 5-8, 9, 10, 11, 12), it is not possible to construct meaningful grade-for-age measures for them.

11. A child is coded as dropped out of high school if he/she does not possess a high school degree and is not currently attending school (this is called status dropout by the US National Center for Education Statistics). A child is coded as below age-appropriate grade if he/she is currently attending grade 8 or lower, or is age 15 and has completed 8 grades or fewer, or is age 16 and has completed 9 grades or fewer, or is age 17 and has completed 10 
What Holds Back the Second Generation?

Our analysis is conducted using the U.S.-born children under age 18 whose parents were childhood immigrants. ${ }^{12}$ We define a childhood immigrant as an immigrant who was under age 18 upon arrival in the United States. For these immigrants, age at arrival is not a choice variable since they did not time their own immigration but merely followed their parents. ${ }^{13}$ We chose the age range for the parents to be 25 to 55 - these individuals would be old enough to have spent years in the United States but young enough to still have children living in the same household. ${ }^{14}$ The census is a cross-sectional data set, and parents can be linked to children only if they reside in the same household. ${ }^{15}$ We stack data on children whose biological father is a childhood immigrant with data on children whose biological mother is a childhood immigrant. Children with two childhood-immigrant biological parents are matched to the mother's characteristics. ${ }^{16}$

We divide our sample into three mutually exclusive language categories: children with parents from non-English-speaking countries of birth, countries of birth with English as an official language that have English as the predominant language, and other countries of birth with English as an official language. ${ }^{17}$ The first category is our "treatment" group and the second is

grades or fewer. This is a rough measure that understates the number of children who are behind a grade. For example, a 17-year-old child who has completed grade 10 observed on Census day in April might be on-schedule because he was born in the fourth quarter and unable to enroll in first grade until he was six years plus nine months old, or he might be behind schedule because he was born in the third quarter, entering school at exactly six years and should already have completed grade 11. It is unfortunate that the public-use 2000 Census microdata provides only age, not month or quarter of birth.

12. For the purposes of this paper immigrant is defined as someone born outside the 50 states and the District of Columbia. This means that a person born in Puerto Rico is considered an immigrant although legally he/she is a US citizen at birth.

13. According to US Citizenship and Immigration Services, immigrating parents may bring any unmarried children under age 21 . We use a more restricted set of childhood immigrants: immigrants who were under 18 upon arrival (that is, maximum age at arrival is 17).

14. The range of year of arrival for the parents is therefore 1945 to 1992. For children aged 5 to 17,80 percent of the parents arrived by 1980. For children aged 15-17, 96 percent arrived by 1980 . We have performed the analysis with a narrower range of years of arrival and the results are basically unchanged. Additionally, it should be noted that our sample (of childhood immigrants who are parents) does not appear to be selected on the basis of English proficiency from the full sample of childhood immigrants - when we estimate Equation 3 described below with the probability of having a child in our sample as the outcome and with data on all childhood immigrants, the coefficient for the instrument is insignificant.

15. We use the MOMLOC and POPLOC variables constructed by IPUMS to match children with their parents within a household.

16. We have performed the analysis using a sample where these children are matched to the father's characteristics instead and the results are basically unchanged. Additionally, the estimated effects of parental English on children's educational outcomes do not differ significantly by sex of the childhood immigrant parent, thus we report only pooled results in this paper.

17. We used The World Almanac and Book of Facts, 1999 to determine whether English was an official language of each country. Recent adult immigrants from the 1980 Census were used to provide empirical evidence of the prevalence of English in countries with English as an official language. English-speaking countries are defined as 
our "control" group. The last category is omitted from the main analysis, since we are not sure how much exposure to the English language immigrants from these countries would have had before immigrating. Table 1 provides the descriptive statistics for the treatment and control groups. Table A1 in the online appendix shows the decomposition of the sample by parents' country of birth and our classification of countries by English-speaking status.

\section{Effect on English Proficiency}

In this section, we quantify the effect of the English proficiency of immigrant parents on the English proficiency of their US-born children. Consider the regression model

$$
\text { (1) } y_{i j a}=\alpha+\beta \text { PARENT_ENG } G_{i j a}+\delta_{a}+\gamma_{j}+\boldsymbol{w}_{i j a}{ }^{\prime} \rho+\varepsilon_{i j a}
$$

for US-born child $i$ with parent born in country $j$ arriving in the US at age $a . y_{i j a}$ is the child outcome, PARENT_ENG $G_{i j a}$ is a measure of parental English-language skills (the endogenous regressor), $\delta_{a}$ is a full set of parental age-at-arrival dummies, $\gamma_{j}$ is a full set of parental countryof-birth dummies, and $\boldsymbol{w}_{i j a}$ is a vector of exogenous explanatory variables (such as age and sex of the child and parent).

To obtain a consistent estimate of the effect of parental English-language skills, $\beta$, we use an instrumental variable that is motivated by the critical period hypothesis for language acquisition (see Newport (2002) for a review). There is believed to be a critical age range in which individuals learn languages more easily and after which language acquisition is more difficult. This appears to be linked to physiological changes in the brain (Lenneberg (1967)). Maturational changes starting just before puberty sharply reduce a child's ability to acquire second languages. In short, younger children - who are still in their critical period - learn languages more easily than adolescents and adults.

Immigrants from non-English-speaking countries will need to learn English to function in American schools, workplaces, and other institutions. Those who arrive at a younger age have a

those countries from which more than half the recent adult immigrants did not speak a language other than English at home. The remaining countries with English as an official language are excluded from the main analysis. We made two exceptions to this procedure. First, despite the fact that Great Britain was not listed as having an official language, we included it in the list of English-speaking countries. Second, we classified Puerto Rico as non-English speaking even though English is an official language due to its colonial history. 


\section{What Holds Back the Second Generation?}

language-learning advantage. On the other hand, younger arrivers likely differ from older arrivers along non-language dimensions that also affect outcomes. Incorporating immigrants from English-speaking countries into the analysis enables us to partial out the non-language effects of age at arrival. This is because upon arrival in the United States, immigrants originating from English-speaking countries encounter everything that immigrants from non-Englishspeaking countries encounter except a new language. Thus, any difference in children's outcomes between young and old arrivers from non-English-speaking countries that is over and above the difference from English-speaking countries can plausibly be attributed to language.

To be more concrete, suppose $Y O U N G_{a}$ is a dummy for parent arriving young and $N O N-E N G_{j}$ is a dummy for parent being born in a non-English-speaking country. Then the exclusion restriction we use for Equation 1 is $Y O U N G_{a} \times N O N-E N G_{j}$. The first-stage equation is:

$$
\text { (2) PARENT_ENG } G_{i j a}=\alpha_{1}+\pi_{1} Y O U N G_{a} \times N O N-E N G_{j}+\delta_{1 a}+\gamma_{1 j}+\boldsymbol{w}_{i j a}{ }^{\prime} \rho_{1}+\varepsilon_{1 i j a}
$$

and the reduced-form equation is:

$$
\text { (3) } y_{i j a}=\alpha_{\mathrm{RF}}+\pi_{\mathrm{RF}} Y O U N G_{a} \times N O N-E N G_{j}+\delta_{\mathrm{RF} a}+\gamma_{\mathrm{RF}_{j}}+\boldsymbol{w}_{i j a}{ }^{\prime} \rho_{\mathrm{RF}}+\varepsilon_{\mathrm{RF} i j a} \text {. }
$$

Note $\pi_{1}$ and $\pi_{R F}$ are difference-in-differences estimators, and can be interpreted as the effect of English-language proficiency under the assumption that non-language age-at-arrival effects are the same for immigrants from non-English-speaking countries and those from English-speaking countries. Since there is not a universal age after which the critical period ends - just as there is variation in the onset of puberty, so there is variation in the age after which language acquisition becomes more difficult - the choice of age cutoff for arriving young appears arbitrary (although the graphical evidence in the next subsection provides some guidance). Thus, in most of our regression analysis, we will be agnostic about where this cutoff is by using as instruments a dummy for each parental age at arrival (age at arrival 0 is omitted) interacted with $N O N-E N G_{j}{ }^{18}$

\section{A. Graphical Evidence}

In our sample of children with at least one childhood immigrant parent, the relationship between immigrants' age at arrival and their English-language skills is strong. This can be seen in Figure 1. The triangle-marker line in Panel A displays the mean English-speaking ability for immigrant

18. The results are not dependent on the specific parameterization of age at arrival in forming the instrument. Table A2 of the online appendix presents results using alternative ways of defining the instrument. 


\section{What Holds Back the Second Generation?}

parents from non-English-speaking countries. Consistent with the research on language acquisition, people who received their first exposure to English at an earlier age attain a higher level of English proficiency than those who received it later. In fact, immigrant parents from non-English-speaking countries who arrive quite young (up to around age 9) attain Englishlanguage skills comparable to those of immigrant parents from English-speaking countries. For later ages of arrival, however, their English-language skills are markedly lower. The squaremarker line in Panel A displays the mean English-speaking ability of the immigrant parents from English-speaking countries. It is flat: nearly every immigrant from English-speaking countries speaks English very well. ${ }^{19}$ This result is as predicted by the theory, since their first exposure to English does not depend on when they migrated to the United States.

Older arrivers have statistically significantly lower English-speaking ability. Figure 1, Panel B, plots for each age at arrival the difference in mean English-speaking ability between parents from non-English-speaking countries and parents from English-speaking countries. Parents who arrived at age 9 or earlier from non-English-speaking countries speak English at least as well as their counterparts from English-speaking countries. ${ }^{20}$ After age at arrival 9, parents from nonEnglish-speaking countries have significantly lower English-speaking proficiency, and indeed the disadvantage increases almost linearly with age at arrival.

Figure 2 shows the relationship between parent's age at arrival and child's English-speaking ability. The negative relationship between parent's age at arrival and children's English-speaking ability is especially pronounced for the younger children. This makes sense because the younger the child, the greater the share of the child's time spent in activities in the home or with the family. As the child attends school longer and participates in more activities outside the home and family, he/she is exposed to more English. For the two oldest child age categories in Figure 2 - spanning ages 13 to 17 - children's English-speaking proficiency does not depend on the parents' English-speaking proficiency. For the younger child age categories, it is striking that the parental age at arrival at which the line turns from relatively flat to downward-sloping is the

19. This line is not mechanically pinned at three because some of these countries have large non-English-speaking communities, for example, the Quebecois in Canada.

20. The significantly higher English proficiency among early arrivers from non-English-speaking countries is an artifact of controlling for Hispanic status, a conventional demographic control variable. If the Hispanic dummy were excluded, the curve in Figure 1, Panel B would shift down but its shape would be unchanged. 
same between Figures 1 and 2. This is supportive of our assertion that the observed relationship between parent's age at arrival and child's English-speaking ability arises from parent's Englishspeaking ability.

\section{B. Instrumental-variables Estimation}

We summarize the relationship between parent's age at arrival and English-language skills depicted in Figures 1 and 2 in a regression framework. Column 1 of Table 2 shows the results of estimating Equation 2, the first-stage equation. The instrument, $Y O U N G_{a} \times N O N-E N G_{j}$ (where $Y_{O U N G}$ is a dummy for arriving by age 9) has strong predictive power for parental English. In particular, just as we saw in Figure 1, immigrants who arrive at a younger age from non-Englishspeaking countries have significantly higher English-speaking ability.

Column 2 of Table 2 shows the results of estimating Equation 3 with child English-speaking ability as the outcome. The reduced-form effect on child's English-speaking ability, although statistically significant, is of a much lower magnitude than the effect on own English-speaking ability. Comparing Columns 1 and 2, the own effect of the instrument on English-speaking ability is almost six times as much as the effect on one's child.

Columns 3 and 4 of Table 2 show the results of estimating Equation 1 by 2SLS. In Column 3, we use $Y O U N G_{a} \times N O N-E N G_{j}$ as the identifying instrument. ${ }^{21}$ For each unit improvement in parental English (say, moving from speaks English well to very well), child's English improves by 0.1692 units among children aged 5 to 17 . In Column 4, we use as identifying instruments a dummy for each parental age at arrival interacted with $N O N-E N G_{j}{ }^{22}$ The effect of parental English on child English is basically unchanged (0.1611). We would have gotten an effect of 0.1849 had we used OLS to estimate Equation 1, so for children aged 5 to 17 as a group, OLS is

21. Since in this case Equation 1 is just identified, the 2SLS coefficient for parental English is equivalent to the indirect least squares estimate obtained by dividing the reduced-form coefficient by the first-stage coefficient for the instrument.

22. We have not reported the coefficients and standard errors associated with the 17 instruments because the same information is conveyed by Figure 1 . With parents arriving at age 0 from non-English-speaking countries as the omitted group, we see no significant coefficients for the interactions for ages at arrival 1 to 9 , and coefficients that are significant, negative and growing in magnitude with age at arrival for interactions for later ages at arrival. Separately, since Equation 1 is now overidentified, we can perform a test of overidentification. The Hansen test suggests that our instruments as a group are exogenous (this is true not only for Table 2, Column 4 but for all our later 2 SLS results). 
upward-biased. A Hausman test does not reject the equality of the OLS and 2SLS estimates at the 5-percent level of significance (the difference between the two estimates is close to significant though - the Hausman test p-value is 0.0559). A priori, we could not have known whether OLS would be upward-biased or downward-biased since, although ability bias would likely cause the former, classical measurement error could cause the latter.

Figure 2 suggested that the effect of parental English on child English would vary by child age, so we have estimated Equation 3 for each child age separately. Figure 3 graphs the 2SLS estimates (triangle-marker line) and OLS estimates (square-marker line) of the effect of parental English by child age. Both lines reveal a positive impact of parental English that is diminishing with child age and disappearing by middle school. ${ }^{23}$ According to the 2SLS estimates, a unit increase in parental English-speaking ability raises 5-year-old children's English-speaking ability by 0.52 units and 10-year-old children's by only 0.08 units. By the time a child is age 12, parent's English-speaking skills would have ceased to matter for the ordinal measure of child's English-speaking skills. A one-unit increase in parental English-speaking ability increases the probability that the child speaks any English significantly by more than one percentage point only for children aged 5 to 6, the probability that the child speaks English well or very well only for children aged 5 to 7, and the probability of speaking English very well for children aged 5 to 12. ${ }^{24}$ Thus, in spite of deficiencies in parental English-language skills, children will learn some English by age 7, learn to speak it well by age 8, and learn to speak it very well by age 13 .

The first main finding of this paper is that parents' English-speaking proficiency has a beneficial effect on children's English-speaking proficiency that is declining with child age and that becomes zero by the time children are in middle school.

\section{Effect on Child Educational Outcomes}

Since limited-English-proficient parents have children who spend their elementary school years

23. 2SLS estimates are larger than OLS estimates for children aged 5 and 6 , and the reverse is true for older children. These differences tend to be significant at the 5-percent level according to Hausman tests.

24. These results are not reported. They come from estimating Equation 1 by child age using 2SLS, but instead of using the ordinal measure of child's English-speaking ability as the dependent variable, the probability that he/she is at a particular level of English-speaking ability is used. 


\section{What Holds Back the Second Generation?}

with poorer English-language skills on average, a logical question is whether this has consequences for children's educational outcomes. In this section, we apply the same techniques we used to estimate the effect of parental English on child English in the previous section to examine educational outcomes for children aged 3 to 7 and 15 to17. (Specific channels through which parental English-language skills might be affecting child educational outcomes are examined in subsection V.B.)

\section{A. Early Educational Outcomes}

We examine the school attendance and grade-for-age of children aged 3 to 7 in Table 3 . We estimate Equation 1 using OLS in Column 1, 2SLS where the interactions between parental ageat-arrival dummies and $N O N-E N G_{j}$ are the identifying instruments (which we will refer to as 2SLS-DD) in Column 2, and 2SLS where the parental age-at-arrival dummies themselves are the identifying instruments (which we will refer to as 2SLS-D) in Column 3. For 3- to 7-year-olds as a group, the estimates suggest that the probability of school attendance is higher for children with more English-proficient parents (see Row 1). This positive effect comes entirely from 3- and 4year-olds. By the time the child is age 5 or higher, all parents are at least as likely to send their children to school, as indicated by the small or insignificant coefficients.

Are children with less English-proficient parents starting K-12 schooling at a later age? The second to last row of Table 3 suggests that 6-year-olds with more English-proficient parents are weakly more likely to be attending kindergarten or higher (the correct grade-for-age for a child who is aged 6 in April 2000 is kindergarten or grade 1). In the last row, 7-year-olds with more English-proficient parents are significantly more likely to be attending first grade or higher (the correct grade-for-age for a 7-year-old is grade 1 or grade 2). These results are not due to differences in state of residence by age at arrival and country of origin, which in turn could generate differences in compulsory schooling laws or school quality and availability -we have augmented the models with state-fixed effects and obtain similar results. These results are consistent with an earlier starting age for K-12 schooling and lower retention rates in kindergarten for children with more English-proficient parents.

We have re-estimated the models restricting the treatment group to be children with Hispanic 


\section{What Holds Back the Second Generation?}

parents (the control group continues to be all children with parents from English-speaking countries), enabling us to obtain estimates for a subpopulation that is considered especially atrisk for poor educational outcomes. ${ }^{25}$ The results, which are shown on the right side of Table 3 , are similar to the results for the overall sample.

The 2SLS estimates of the effect of parental English tend to be larger than the OLS estimates, significantly so in a few cases. ${ }^{26}$ The estimates of the effect of English proficiency on children's early educational outcomes are overall downward biased. Apparently, the downward bias caused by measurement error more than offset the upward bias caused by ability-bias-type stories.

It is worth making a comment about the two alternative 2SLS estimates, 2SLS-DD and 2SLS-D. In general in Table 3, they lead to the same qualitative result. However, it is apparent for the outcome, 7-year-old attending first grade or higher, the 2SLS-DD estimate is much larger in magnitude-albeit much less precise-than the 2SLS-D estimate. Recall that the 2SLS-DD estimator relies on the assumption that the difference in child outcome between younger arrivers and older arrivers would have been the same among immigrants from non-English-speaking countries and those from English-speaking countries. A priori, we thought that the non-language age-at-arrival effects would work against the older arrivers, that is, adjustment to U.S. institutions would be more difficult for the older arrivers and their children would do worse. It turns out, however, that for several child educational outcomes (this one, and the teen educational outcomes below), among parents from English-speaking countries, the older arrivers have children who are doing better than the younger arrivers. ${ }^{27}$ This means that controlling for non-language age-at-arrival effects actually increases, rather than decreases, the estimated benefit of parental English. A story consistent with this is that less assimilated parents are stricter or care more about education, so their children have better educational outcomes. But another possible interpretation is that immigrants from English-speaking countries might be poor controls for the nonlanguage effects of age at arrival that immigrants from non-English-speaking

25. The sample used for this analysis is about two-thirds of the original one.

26. Hausman tests indicate that the 2SLS-DD estimate of the effect on 7-year-old attending first grade or higher is significantly different from the OLS estimate (p-value is 0.0148), and both 2SLS estimates of the effect on 3-4-yearolds attending school are different from the corresponding OLS estimates (p-value is 0.0644 for the test involving the 2SLS-DD estimate and 0.0195 for the test involving the 2SLS-D estimate).

27. An examination of the right side of Table 1 , Panel $\mathrm{C}$ reveals this. 
countries experience. For people who take the latter view, the 2SLS-D estimates might be preferable - these estimates assume non-language age-at-arrival effects are zero, which given the present situation leads to lower estimated benefits of parental English on child educational outcomes. Also, in subsection V.A, we pursue several strategies to enhance the comparability between immigrants from English- and non-English-speaking countries.

A second main finding of this paper is that young children with more English-proficient parents are more likely to attend preschool and start first grade on time. According to 2SLS-DD estimates, a one-unit increase in parental English-speaking ability increases the probability that 3- to 4-year-olds attend school by 9.39 percentage points (which is one-quarter of the mean attendance rate for 3- to 4-olds with parents from non-English-speaking countries) and decreases the probability that 6- to 7-year-olds are below their age-appropriate grade by 1.93 percentage points (which is two-thirds of the mean percent below age-appropriate grade). These effects of parental English are therefore economically meaningful in size. ${ }^{28}$

\section{B. Longer-run Educational Outcomes}

We turn to the educational outcomes of children aged 15 to 17 . These children are close to the legal school-leaving age but generally still live with their parents. Table 4 presents the results of estimating Equation 1 using OLS, 2SLS-DD, and 2SLS-D. The top half shows results for probability of dropping out of high school. In Row 1, for 15- to 17-year-olds as a group, all the estimates are negative and significant. The 2SLS-DD estimate in Column 2 suggests that a one unit increase in parental English-speaking ability reduces the probability of child dropping out of high school by 1.77 percentage points, which is about 80 percent of the mean high school dropout rate for children with parents from non-English-speaking countries.

The bottom half of Table 4 shows results for probability of being below the age-appropriate

28. They do not appear unreasonably large though. A one-unit increase in the parental English ordinal measure corresponds to a one-standard-deviation increase among older-arriving parents from non-English-speaking countries. The measure of parental English is not normally distributed-it is a scale of 0 (speaks no English) to 3 (speaks English very well) with few people at 0 and many people at 3 . However, among older-arriving parents from non-English-speaking countries, individuals are roughly evenly divided among categories 1 to 3 (with few in category 0 ), which means that a one-unit increase corresponds to moving up one tercile on the language scale. This is a sizable movement. Moreover, as we discuss below, concomitant with this movement is a significant increase in parental schooling and family income, which also affect child outcomes. 
grade. As discussed in subsection II.B, our measure of this outcome is very rough and likely fails to capture some students who are only one grade behind vis-à-vis their on-schedule school progression based on their birth date and relevant compulsory schooling laws. We find that parental English has a negative and significant effect on the probability of the child falling behind their appropriate grade-for-age. For 15- to 17-year-olds as a group, the 2SLS-DD estimate in Column 2 suggests that a one unit increase in parental English-speaking ability reduces the probability of being below the age-appropriate grade by 4.32 percentage points, which is about 60 percent of the mean percent below age-appropriate grade for children with parents from non-English-speaking countries.

For both teen educational outcomes, the 2SLS estimates of the effect of parental English tend to be larger than the OLS estimates, though never significantly so at conventional levels. ${ }^{29}$ Also, the 2SLS-D estimates in Column 3 are smaller in magnitude than the 2SLS-DD estimates. The reason for the difference between the two 2SLS estimates is as mentioned in the previous subsection - among children with parents from English-speaking countries, the children of older arrivers have better educational outcomes than the children of younger arrivers.

We have re-estimated the models restricting the treatment group to be children with Hispanic parents (the control group continues to be all children with parents from English-speaking countries) and displayed the results on the right side of Table 4 . The results are similar.

A third main finding of this paper is that teenagers with more English-proficient parents are less likely to drop out of high school and be below their age-appropriate grade.

\section{Robustness/Specification Checks}

\section{A. Comparability of the Control and Treatment Countries}

In this subsection, we consider and discard several alternative hypotheses for the results above

29. There are no differences at the 5-percent significance level. The p-value for the Hausman tests comparing the 2SLS-DD estimate to the OLS estimate is under 0.15 only for the following outcomes: dropping out of high school for 15-17-year-olds as a group (0.1091) and for 15-year-olds only (0.1113), and being below-age-appropriate grade for 17-year-olds only (0.0889). 


\section{What Holds Back the Second Generation?}

on child English-speaking ability and educational outcomes.

One concern is that many low-educated young men migrate on their own to the United States from Mexico and Central America to look for work. Among the older arrivers from non-Englishspeaking countries, there may be a disproportionate number of low-educated immigrants who never intended (or were never able) to attend school in the United States, and moreover who differ along other dimensions as well since they chose to migrate on their own. There is no way of identifying which immigrants were "loner migrants," as we have a cross-section in which all childhood immigrants are currently adults. Instead, we redo our analysis dropping the oldest arrivers. Table 5, Panel B shows the results after excluding children with parents who arrived at age 16 or 17. Overall the estimated effects are similar to the base results (reported in Panel A).

A second concern is that English-speaking countries and non-English-speaking countries may differ in ways that affect the assimilation process in the United States of emigrants. On the one hand, it is possible that immigrants from non-English-speaking countries exhibit a stronger ageat-arrival effect simply because immigrants from poorer countries face additional barriers to adaptation and that these barriers increase in severity as a function of age at arrival. This is plausible because non-English-speaking countries tend to be poorer than English-speaking countries. Richer countries tend to have better school systems, such that a year of schooling in richer countries would be a closer substitute for a year of schooling in the United States. It is plausible, then, that immigrants from non-English-speaking countries on average receive a lower return for each year of schooling received in the home country (because schooling back home is so different) and a higher return for each year of schooling received in the United States (because there is so much new in the United States and much catch-up) than immigrants from nonEnglish-speaking countries. This would mean that interactions between parental age at arrival and $N O N-E N G_{j}$ are invalid exclusion restrictions in Equation 1. One way to address this problem is to control explicitly for the interaction between parental years of schooling obtained in the United States and $N O N-E N G_{j}$. This ends up not being feasible so we take a more indirect approach. ${ }^{30}$ We allow parental age-at-arrival effects to differ by school quality in the parental

30. We view years of schooling as an outcome of English proficiency (see Bleakley and Chin (2004a)), which argues against controlling for parental schooling in the US and interactions thereof. Still, this leaves open the 
country of birth. We use three proxies for school quality: per capita GDP, per-pupil school expenditures at the primary level, and teacher-pupil ratio at the primary level. ${ }^{31}$ In Panels C-E, we include as a control variable an interaction between parental age at arrival and each of the three proxies in turn. ${ }^{32}$ The results are similar to the base results. In Panel F and G, we estimate effects of parental English separately for children with parents from below-median-GDP countries and above-median-GDP countries. Although effects are generally similar for both groups, effects tend not to be significant for the richer country group partly because of the fewer observations. ${ }^{33}$ A notable difference between Panels E and F, though, is in the 2SLS-D estimates for the teen educational outcomes - parental English improves educational outcomes only for teenagers with parents from poor countries.

On the other hand, English-speaking countries might have greater cultural and institutional similarity to the United States, making adjustment easy for immigrants from these countries irrespective of age at arrival. In contrast, immigrants from non-English-speaking countries encounter both a foreign language and foreign culture, so even ignoring the language there is more to adjust to for the older arrivers. To address this problem, we restrict analysis to groups of countries that might be more similar to each other. In Panel H, we drop children of immigrants

possibility of controlling for potential parental schooling in the United States by age 16 (this has less endogeneity problems since it is just based on age at arrival and not individual choices about school attendance) interacted with parent being from a non-English-speaking country. We have done this (results are not reported), and although the 2SLS effects on child educational outcomes are the same sign as the base results, none of them are statistically significant. Moreover, the coefficient for potential parental schooling in the United States by age 16 interacted with parent being from a non-English-speaking country is never significant in the child education regressions. This is perhaps not surprising given the high degree of collinearity between the source of identification (younger children learn language more easily than older children, with older children having a disadvantage that is growing almost linearly with age at arrival) and the added control (younger children have more years of potential schooling in the US than older children, with children having one fewer year for each year past school entry age 6 that they arrive).

31. These are from the data sets constructed and described by Lee and Barro (1997) and Summers and Heston (1988). We use the values for 1965 because parents in the 2000 Census sample would be exposed not to contemporaneous conditions in their country of birth but conditions prevailing when they were children.

32. For parsimony, the specific parameterization of this control is $\max (0$, age at arrival- 6$) \times$ school quality proxy in parent's country of birth. The rationale for using the piecewise linear function of age at arrival is that immigrants who arrived in the United States at age 6 or earlier would not have been exposed to the school system in the origin country while older arrivers would have (age at arrival -6) years of potential exposure to origin-country schooling (since 6 is often the age of entering grade 1). We have used other parameterizations of this control and the results are similar.

33. The median GDP is calculated based on the sample of children aged 3 to 17 from all countries, and since Mexico is the median country of origin, accounts for about 40 percent of the total sample, and falls in the below-median category, the number of observations in the below-median category is about 2.5 times that in the above-median category. It should be noted, however, that the findings of the paper are not driven by the children of Mexican immigrants alone- the findings remain even when we drop them from the analysis. 
from Canada. These children account for one-third of the observations of children of immigrants from English-speaking countries, yet they may be poor controls for the assimilation process of the average immigrant due to Canada's geographic proximity to the United States and status as a former British colony. The results remain. ${ }^{34}$ In Panel I, we restrict analysis to children of parents who emigrated from the Caribbean. In Panel J, we restrict analysis to children of parents who emigrated from Europe or Canada. When looking within a geographic region, the control and treatment countries are likely more similar in terms of their economic and historical backgrounds. The estimates in Panels I and J support the implications of the base results although understandably they are less precise.

A third concern is that the years the parent spent in the United States prior to having the child may affect outcomes in a way that varies by the English-speaking status of the parental country of birth. Because on average people who arrive at an earlier age have lived in the United States longer, then to the extent that a year of U.S. experience confers differential non-language-related returns to immigrants from non-English-speaking countries, it is invalid to use interactions between parental age at arrival and $N O N-E N G_{j}$ as instruments. This problem is mitigated by the fact that our sample (described in Table 1) is comprised of children whose parents have been in the United States for an average of 28 years. These immigrant parents would have had ample opportunities to learn what they can about American institutions and language already, such that additional years in the United States make little difference. However, we do recognize that parental English-language skills measured in the 2000 Census may differ from the skills that prevailed at the time the child was born, and it would be desirable to account for the possibility that some parents may have had their children soon after arriving in the United States when differential non-language-related returns to years in the United States may have applied. It is not possible to control explicitly for parental years spent in the United States interacted with NON$E N G_{j}$ and still use our instruments. ${ }^{35} \mathrm{~A}$ feasible approach is to restrict the analysis to children whose parents had spent a long time in the United States prior to their birth. In Table 5, Panel K, we keep only the children whose parents had spent at least one decade in the United States prior

34. The results remain even when we also exclude children with parents from England, Scotland, Wales, Australia and New Zealand from the analysis.

35. This is because years the parent spent in the US prior to having the child is a linear combination of variables in the model: parent's age at arrival (三parent's age in year 2000-(2000-year of immigration)), parent's age, child's age, and a constant. 


\section{What Holds Back the Second Generation?}

to their birth (this is three-quarters of the original sample) and obtain results that are similar to the base results.

\section{B. Channels of the Effects of Parent's English-Language Skills}

To what extent are the effects of parental English-language skills on child educational outcomes mediated through parental education, family income and some other variables related to the home environment that parental English has been documented to affect? First, parents with better English-language skills have significantly higher educational attainment (Bleakley and Chin (2004a)). ${ }^{36}$ This may inspire children to pursue more education and improve parents' ability to gather information, communicate with the school and help with school assignments. In Table 6, Panel B, we examine how the estimated effect of parental English changes once we control for parental years of schooling. We see that the effects on children's educational outcomes are often greatly diminished (especially for the 2SLS-D estimates in the even columns), which is consistent with schooling being a key mechanism for the effect of parental English on children's educational outcomes.

Second, parental English-language skills may improve child outcomes through increasing earnings (for example, Angrist and Lavy (1997); Dustmann and van Soest (2002); and Bleakley and Chin (2004a)). ${ }^{37}$ Children grow up with greater financial security in neighborhoods with better schools, which could improve outcomes. In Table 6, Panel $\mathrm{C}$ we control for family income. Although family income tends to improve children's outcomes, the reduction in the estimated benefits of parental English is modest.

Third, the effects of parental English proficiency may be mediated through labor force participation. Bleakley and Chin (2007) find that higher English proficiency increases the probability of working for female childhood immigrants and for wives of male childhood immigrants (men tend to have a high level of participation that is not sensitive to English proficiency). It is theoretically ambiguous what the consequences are for children's outcomes

36. In our sample of children aged 5 to 17, a one-unit increase in parental English leads to a 3 -year increase in years of schooling according to the 2SLS-DD and 2SLS-D estimates.

37. In our sample of children aged 5 to 17 , a one-unit increase in parental English leads to approximately a 25 percent increase in family income according to the 2SLS-DD and 2SLS-D estimates. 
since, although the working parent will raise family income and gain more exposure to the English-speaking world, he/she will have less time to spend with his/her child. In Panel D of Table 6, we control for the childhood immigrant parent working last year. ${ }^{38}$ On average, working improves children's outcomes, but the reduction in the estimated benefits of parental English through the employment channel is even more modest than the income channel.

To summarize Table 6, parental education appears to be an important intermediary for the effect of parental English-language skills on children's educational outcomes. Family income and parental employment status play smaller roles. ${ }^{39}$ If immigrants from English-speaking countries were good controls for the non-language age-at-arrival effects experienced by immigrants from English-speaking countries, then we would prefer the 2SLS-DD estimates and conclude that there could still be a role for other channels (the odd columns of Panel E show point estimates that suggest a benefit of parental English that is at least 40 percent of the base estimates, though they tend to be insignificant). If we preferred the 2SLS-D results, then parental schooling is the primary intermediary via which parental English affects child educational outcomes, and there does not appear to be a role for other channels (the even columns of Panel $\mathrm{E}$ show point estimates that are close to zero and sometimes opposite-signed).

Other channels for the effect of parental English on children's educational outcomes might include the following. First, parents' English-language skills affect children's English-language skills, which in turn affect children's educational outcomes. Note in Table 6, Columns 1 and 2 that the estimated effect of parental English on young children's English proficiency barely changes after controlling for the parental schooling, family income and parental employment status channels. This is consistent with parental English having a direct role in the development of children's English-language skills, such as through using English at home. Even though our analysis using Census data suggests that children with less-English-proficient parents catch up in

38. We have also estimated models controlling for mother working last year-where the sample is restricted to twoparent families - and obtained similar results.

39. In results not reported, we have also controlled for several other potential intermediating variables and found that they did not materially change the estimated effect of parental English: whether child is in a two-parent household, family size, and "neighborhood of residence". We used two measures of "neighborhood of residence": dummies for super-public use microdata area (an area smaller than the state containing a minimum of 400,000 residents) and the percent of the population in the public use microdata area (an area containing a minimum of 100,000 residents) that has the same country of birth as the childhood immigrant parent. 


\section{What Holds Back the Second Generation?}

English-speaking ability by middle school, there could remain differences in richer measures of English-language skills such that even longer-run children's educational outcomes are impacted through this channel. (We explore this possibility in the next subsection.) Second, even if the English-language skills of children with less English-proficient parents did catch up in all meaningful ways, it may be difficult to undo the accumulated effects of spending the elementary school years labeled as limited English proficient. Third, more English-proficient parents might be more adept at helping with children's school assignments or maneuvering their children into the classes, programs and schools that position their children to succeed.

\section{Alternative Measures of English Proficiency}

In Section III, we found that children whose parents have lower English-speaking proficiency themselves have lower proficiency throughout elementary school, but catch up by middle school. The "language gap" may well extend beyond the elementary school years, but we are unable to detect this because of the bluntness of the English-language measure provided by the Census. Oral language proficiency develops more easily than the wider range of language skills needed for success in high school and thereafter, and it is possible that children of immigrants who speak English very well are still behind in this wider range of English-language skills. ${ }^{40}$ To assess this, we consider more detailed language measures from the National Longitudinal Survey of Youth 1979 (NLSY) (US Department of Labor Bureau of Labor Statistics (2002)). Since we cannot replicate our instrumental-variables strategy with this dataset, we present these results as suggestive only.

The NLSY is a nationally representative sample of individuals aged 14 to 22 in 1979 . The Armed Services Vocational Aptitude Battery (ASVAB) was administered to these individuals in 1980. The ASVAB contains 10 subtests, including ones that assess English-language skills. We find that among US-born individuals with at least one immigrant parent in the NLSY, those who grew up in homes where a foreign language was spoken tend to perform worse on subtests most related to English-language skills. This is shown in Figure 4, which displays estimated densities of residualized scores of four subtests by whether a foreign language was spoken at the respondent's childhood home. Panels A and B show the results for the vocabulary test and 
reading comprehension test, respectively. Among the subtests in the ASVAB, these two are the most evidently language-oriented. The estimated distributions are markedly different, with those from foreign-language childhood homes having more mass in the lower end. Panel $\mathrm{C}$ plots the densities for the arithmetic test. While it is sometimes said that mathematics is the universal language, the observed differences between the two distributions is consistent with the importance of English proficiency at younger ages. Arithmetic is taught in the early grades, precisely when we saw above that the second generation's English proficiency is most affected by parental English. Additionally, the subject is typically taught by rote repetition and memorization, in English, of key phrases ("two plus two is four," etc.). Moreover, there is evidence that exact arithmetic depends on language and uses a part of the brain that is also used to generalize associations between words (Dehaene et al. (1999). The coding-speed test, summarized in Panel D, is a measure of processing speed that consists of matching items (numbers, names, etc.) in two different lists. This is perhaps the most language-content-free test, and it shows the least difference between the two groups. In fact, there is less mass in the lower scores for those from foreign-language childhood homes. We view Panel D as a control experiment; it is revealing that children with a foreign-language background do significantly worse on tests that have more rigorous requirements for English-language skills but no worse on tests without them.

The evidence from NLSY, then, supports the idea that although U.S.-born children with limitedEnglish-proficient parents eventually catch up in terms of the Census measure of Englishlanguage skills (which is in a few discrete categories and relates to speaking ability only), they continue to lag behind in terms of richer measures of English-language skills. Even as teenagers and adults, individuals with less English-proficient parents continue to have worse Englishlanguage skills. ${ }^{41}$

41. In Table A3 of the online appendix, we present further evidence that children's English-language skills may be worse beyond elementary school using data from the National Education Longitudinal Study of 1988 (NELS). This table also examines a variety of children's educational outcomes. The NELS analysis supports the findings in this paper, and additionally shows that children with less English-proficient parents are less likely to get an associate's or bachelor's degree. We cannot replicate our instrumental-variables strategy using the NELS data, therefore we do not emphasize these results. 


\section{What Holds Back the Second Generation?}

\section{Conclusions}

Children whose parents have lower English proficiency have significantly worse Englishlanguage skills for at least the first 11 years of their lives. Although they eventually catch up in English-speaking ability to the children whose parents are more English-proficient by middle school at least as measured by the Census, there appear to be permanent detrimental effects of poor parental English-language skills. They are less likely to attend preschool, more likely to be behind their age-appropriate grade, and more likely to drop out of high school. This has negative consequences in terms of human capital formation - there are fewer years of schooling and moreover the same years of schooling may encapsulate quite distinct skills and knowledge developed for children whose parents differ in English proficiency. English is the language of instruction and interaction in U.S. schools, and command of English enhances the ability of the child to learn and follow directions. Children who start school with limited English-language skills will learn less given the same instruction, and may even be relegated to less rigorous instruction. Additionally, due to grade repetition, children with less English-proficient parents would have been exposed to less content in the classroom since some of the content is repeated.

Parental education seems to be an important mediator of the effect of parental English-language skills on child educational outcomes. Still, even after controlling for the parental education channel and other socioeconomic-status-type channels that we a priori thought were important, there remains a role for direct channels. Direct channels include teaching the child Englishlanguage skills, helping the child with school assignments, and maneuvering to get the child into the right classes and schools. This suggests that adult English classes, which may impart limited private returns (to the extent that English-language skills raise earnings through increasing years of schooling, then earnings may not be much affected), may nevertheless provide significant social returns.

School-based English-learning programs for older childhood immigrants upon their arrival in the United States from non-English-speaking countries would have greater social returns than adult English classes. The payoff of possessing English-language skills while in middle school or high school are much greater - the private returns are higher, and from a social perspective the 
benefits for the children are accrued without having to incur the costs of adult English classes. In future research we will attempt to evaluate different programs targeted toward limited-Englishproficient children. The benefits of finding programs that raise English proficiency are even higher than previously thought. 
What Holds Back the Second Generation?

\section{References}

Angrist, Joshua D., and Victor Lavy. 1997. "The Effect of a Change in Language of Instruction on the Returns to Schooling in Morocco." Journal of Labor Economics 15(1):S48-S76.

Black, Sandra E., Paul J. Devereux, and Kjell G. Salvanes. 2005. "Why the Apple Doesn't Fall Far: Understanding Intergenerational Transmission of Human Capital." American Economic Review 95(1):437-449.

Bleakley, Hoyt, and Aimee Chin. 2004a. "Language Skills and Earnings: Evidence from Childhood Immigrants." Review of Economics and Statistics 86(2):481-496.

. 2004b. "What Holds Back the Second Generation? The Intergenerational Transmission of Language Human Capital Among Immigrants," Center of Comparative Immigration Studies Working Paper 104. San Diego, CA: University of California at San Diego.

. 2007. "English Proficiency and Social Assimilation among Childhood Immigrants: An Instrumental-Variables Approach." Center of Comparative Immigration Studies Working Paper 149. San Diego, CA: University of California at San Diego.

Card, David, John DiNardo, and Eugena Estes. 2000. "The More Things Change: Immigrants and the Children of Immigrants in the 1940s, the 1970s, and the 1990s." In Issues in the Economics of Immigration, ed. George J. Borjas, 227-270. Chicago: University of Chicago Press.

Casey, Teresa, and Christian Dustmann. 2005. "Intergenerational Transmission of Language Capital and Economic Outcomes." Centre for Research and Analysis of Migration Discussion Paper No 06/05. London: University College London.

Collier, Virginia P. 1995. “Acquiring a Second Language for School.” Directions in Language and Education Series No. 14. Washington, DC: National Clearinghouse for Bilingual Education.

Currie, Janet, and Enrico Moretti. 2003. "Mother's Education and the Intergenerational Transmission of Human Capital.” Quarterly Journal of Economics 118(4):1495-1532.

Dehaene, S., E. Spelke, P. Pinel, R. Stanescu, and S. Tsivkin. 1999. "Sources of Mathematical Thinking: Behavioral and Brain-Imaging Evidence.” Science 284(5416): 970-974.

Dustmann, Christian, and Arthur van Soest. 2002. "Language and the Earnings of Immigrants." Industrial and Labor Relations Review 55(3):473-492.

Farkas, George, and Kurt Beron. 2004. "The Detailed Age Trajectory of Oral Vocabulary Knowledge: Differences by Class and Race.” Social Science Research 33(3):464-497. 


\section{What Holds Back the Second Generation?}

Glick, Jennifer E., and Michael J. White. 2003. "The Academic Trajectories of Immigrant Youths: Analysis Within and Across Cohorts.” Demography 40(4): 759-783.

Grogger, Jeffrey, and Stephen J. Trejo. 2002. Falling Behind or Moving Up? The

Intergenerational Progress of Mexican Americans. San Francisco: Public Policy Institute of California.

Hakuta, Kenji, Yuko Goto Butler, and Daria Witt. 2000. "How Long Does it Take English Learners to Attain Proficiency?” UC LMRI Policy Report 2000-1. Santa Barbara, CA: University of California Linguistic Minority Research Institute.

Hart, Betty, and Todd Risley. 1995. Meaningful Differences in Everyday Experience of Young American Children. Baltimore: Paul Brookes Publishing Company.

Hernandez, Donald J., and Evan Charney, eds. 1998. From Generation to Generation: The Health and Well-Being of Children in Immigrant Families. Washington, DC: National Academy Press.

Hirschman, Charles. 2001. "The Educational Enrollment of Immigrant Youth: A Test of the Segmented-Assimilation Hypothesis.” Demography 38(3):317-336.

Kominski, Robert. 1989. "How Good Is 'How Well'? An Examination of the Census EnglishSpeaking Ability Question." Presented at the 1989 annual meeting of the American Statistical Association, Social Sciences Section. Washington, DC: US Census Bureau, Population Division.

Lee, Jong-Wha, and Robert J. Barro. 1997. "Schooling Quality in a Cross Section of Countries." NBER Working Paper No. 6198. Cambridge, MA: National Bureau of Economic Research. (Data accessed from http://www.nber.org.)

Lenneberg, Eric H. 1967. Biological Foundation of Language. New York: Wiley \& Sons.

Leon, Alexis. 2003. "Does 'Ethnic Capital' Matter? Identifying Peer Effects in the Intergenerational Transmission of Ethnic Differentials.” MIT Department of Economics mimeo.

Newport, E.L. 2002. “Critical Periods in Language Development.” In Encyclopedia of Cognitive Science, ed. L. Nadel, 737-740. London: Macmillan Publishers Ltd./ Nature Publishing Group.

Oreopoulos, Philip, Marianne E. Page, and Ann Huff Stevens. 2006. "The Intergenerational Effects of Compulsory Schooling." Journal of Labor Economics 24(4):729-760.

Portes, Alejandro, and Lingxin Hao. 1998. "E Pluribus Unum: Bilingualism and Language Loss in the Second Generation." Sociology of Education 71(4):269-294. 
Portes, Alejandro, and Dag MacLeod. "Educating the Second Generation: Determinants of Academic Achievement Among Children of Immigrants in the United States." Journal of Ethnic and Migration Studies 25(3):373-396.

Ruggles, Steven, Matthew Sobek, Trent Alexander, Catherine A. Fitch, Ronald Goeken, Patricia Kelly Hall, Miriam King, and Chad Ronnander. 2004. Integrated Public Use Microdata Series: Version 3.0 [machine-readable database]. Minneapolis, MN: Minnesota Population Center [producer and distributor]. (Data accessed from http://www.ipums.org.)

Smith, James P. 2003. “Assimilation Across the Latino Generations.” American Economic Review Papers and Proceedings 93(2):315-325.

Summers, Robert, and Alan Heston. 1988. “A New Set of International Comparisons of Real Product and Price Levels Estimates for 130 Countries, 1950-1985." Review of Income and Wealth 34(1):1-25. (Penn World Tables (Mark 5.6a) data accessed from http://www.nber.org.)

Suro, Roberto, and Jeffrey S. Passel. 2003. "The Rise of the Second Generation: Changing Patterns in Hispanic Population Growth," Pew Hispanic Center Report, October 14. Washington, DC: Pew Hispanic Center.

US Department of Labor, Bureau of Labor Statistics. 2002. National Longitudinal Survey of Youth 1979 Cohort, 1979-2002 (rounds 1-20) [computer file]. Columbus, OH: Center for Human Resource Research, the Ohio State University [producer and distributor].

World Almanac and Book of Facts, 1999. 1998. Mahwah, NJ: World Almanac Books.

Zehler, Annette M., Howard L. Fleischman, Paul J. Hopstock, Todd G. Stephenson, Michelle L. Pendzick, and Saloni Sapru. 2003. Descriptive Study of Services to LEP Students and LEP Students with Disabilities, Volume IA Research Report - Text. Washington, DC: Department of Education. 
Figure 1. English-Speaking Ability by Age at Arrival for Immigrant Parents

Panel A. Regression-Adjusted Means

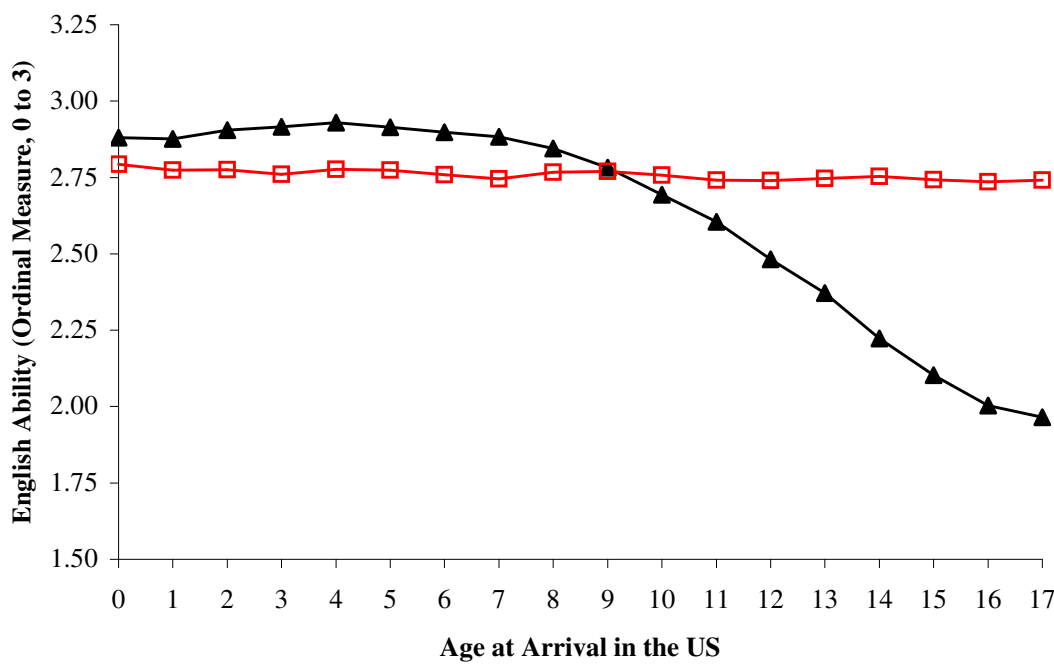

$\rightarrow$ Non-English-speaking country of birth $\square$ English-speaking country of birth

Panel B. Difference in Means

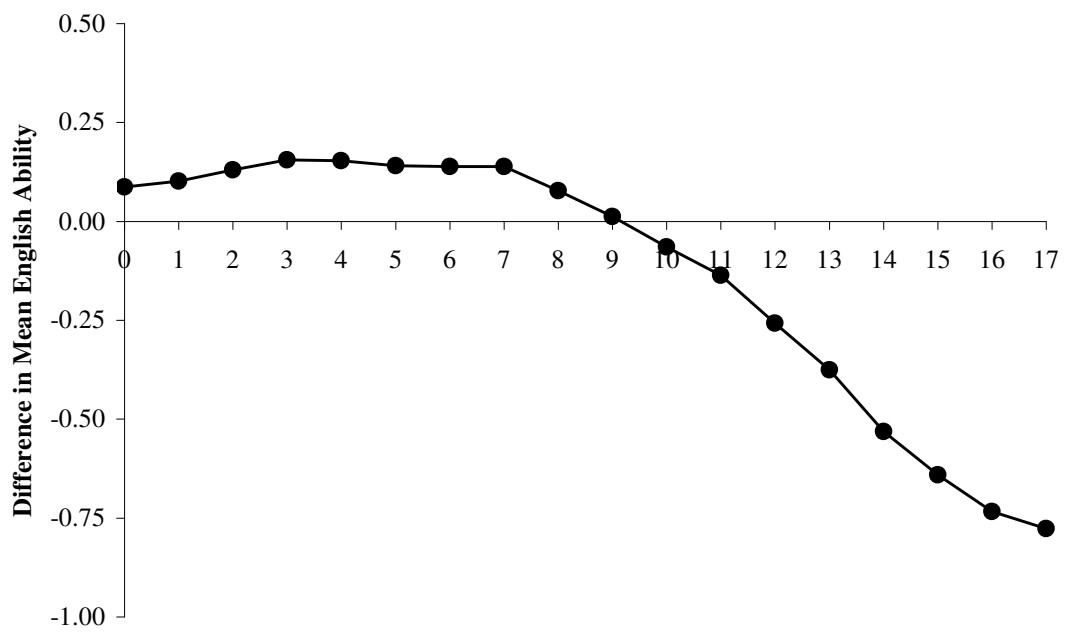

Age at Arrival in the US

Notes: The sample is as described in Table 1 notes. In Panel A, displayed for each age at arrival is the mean Englishspeaking ability for the immigrant parent. In Panel B, displayed for each age at arrival is the difference in mean Englishspeaking ability between parents from non-English-speaking countries and parents from English-speaking countries. Statistics are weighted by child-level IPUMS weights, and regression-adjusted for dummies for age, sex, race, and Hispanic status of the parent who is the childhood immigrant, and dummies for the age and sex of the child. The English-speaking ability ordinal measure is defined as: $0=$ no English, $1=$ not well, $2=$ well, and $3=$ very well. 
Figure 2. Child's English-Speaking Ability

by Immigrant Parent's Age at Arrival and Child's Age

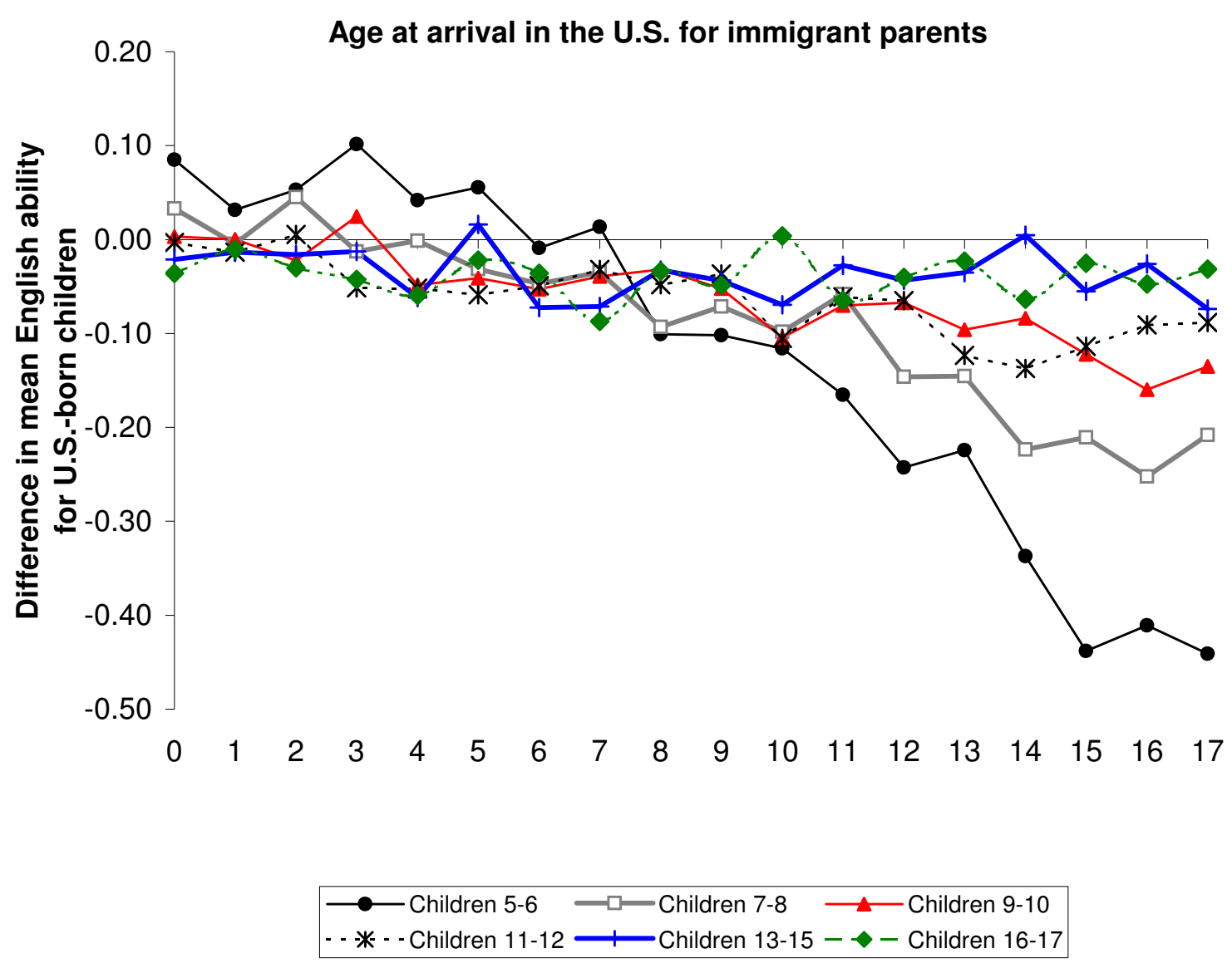

Notes: Displayed for each parental age at arrival is the difference in mean English-speaking ability between children with parents from non-English-speaking countries and children with parents from English-speaking countries. Sample and method are as described in Figure 1 notes. 


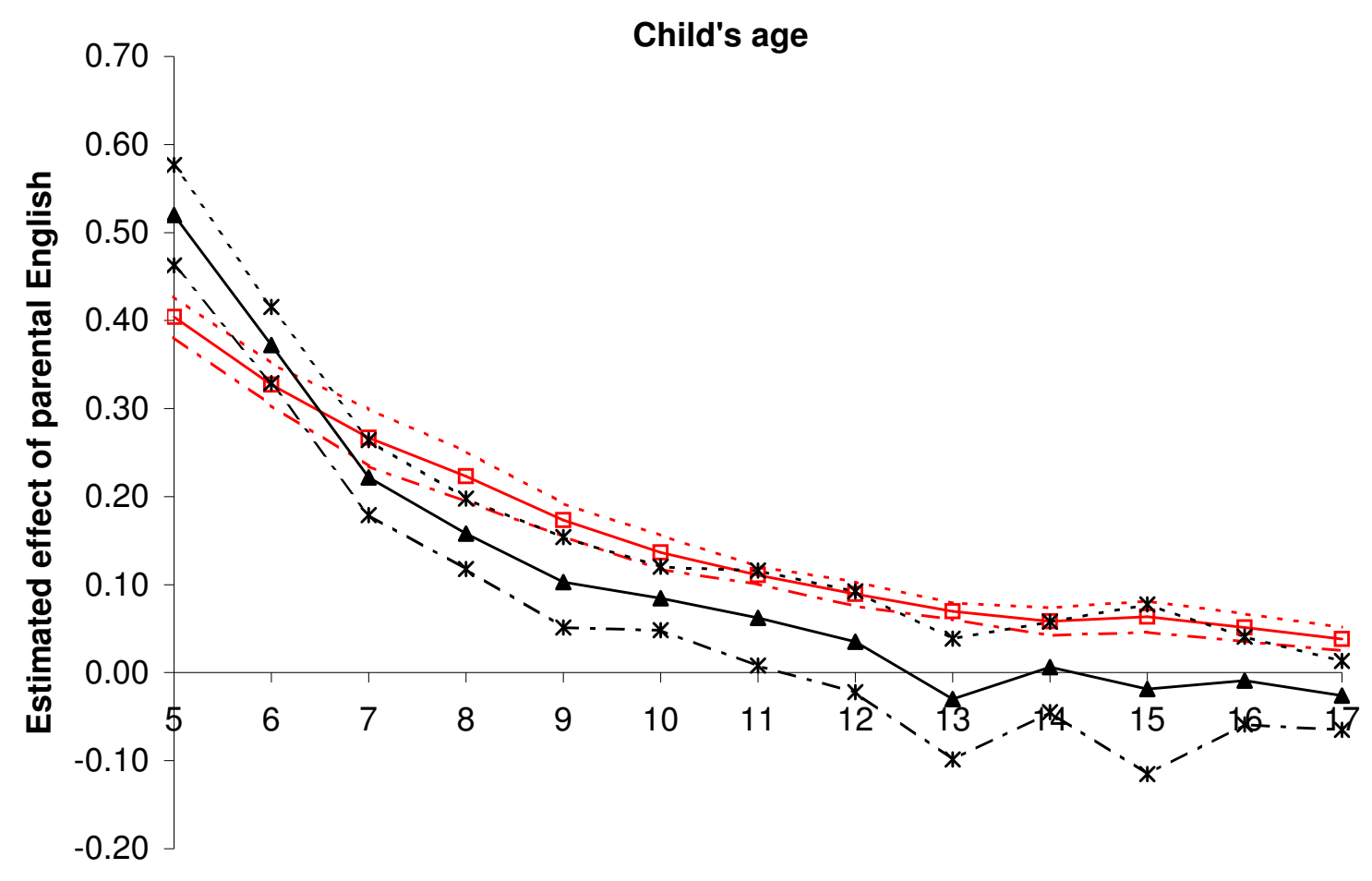

\begin{tabular}{|c|c|}
\hline$\square-C$ & $95 \% \mathrm{Cl}$ \\
\hline$-2 S L S \epsilon$ & $6 \mathrm{Cl}$ \\
\hline
\end{tabular}

Notes: The square-marker line shows the OLS coefficient for parental English for each child age. The triangle-marker line shows the 2SLS coefficient for parental English for each child age. The dotted lines show the 95 percent confidence interval (Cl) bands for the OLS and 2SLS estimates (based on robust standard errors adjusted for clustering by parental country of birth). Each coefficient comes from a separate regression estimated using 2000 IPUMS data that also contains dummies for the age at arrival, country of birth, age, sex, race, and Hispanic status of the parent who is the childhood immigrant, and dummies for the age and sex of the child. The identifying instruments for the 2SLS estimates are interactions between dummies for parental age at arrival and dummy for parent being born in a non-English-speaking country. 
Figure 4. Kernel Density Estimates of ASVAB Scores by Home Language

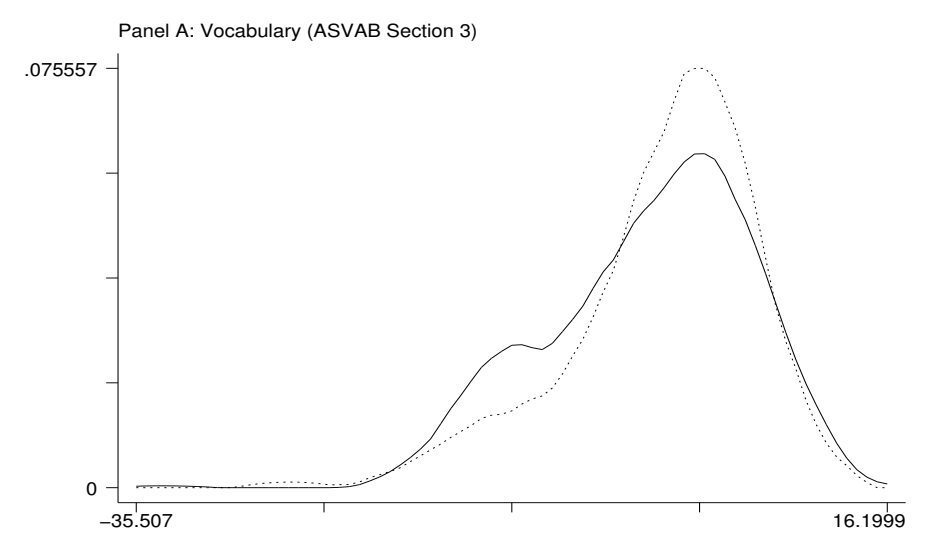

Panel C: Arithmetic (ASVAB Section 2)

.060662

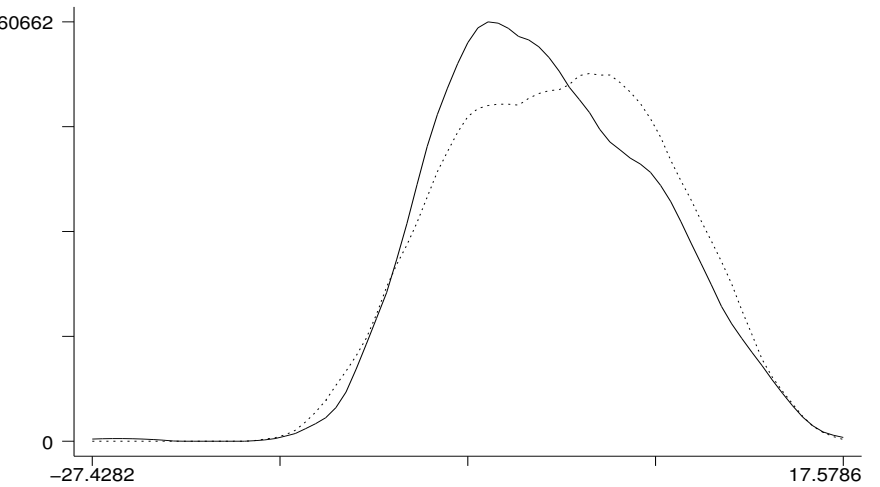

Panel B: Reading Comprehension (ASVAB Section 4)

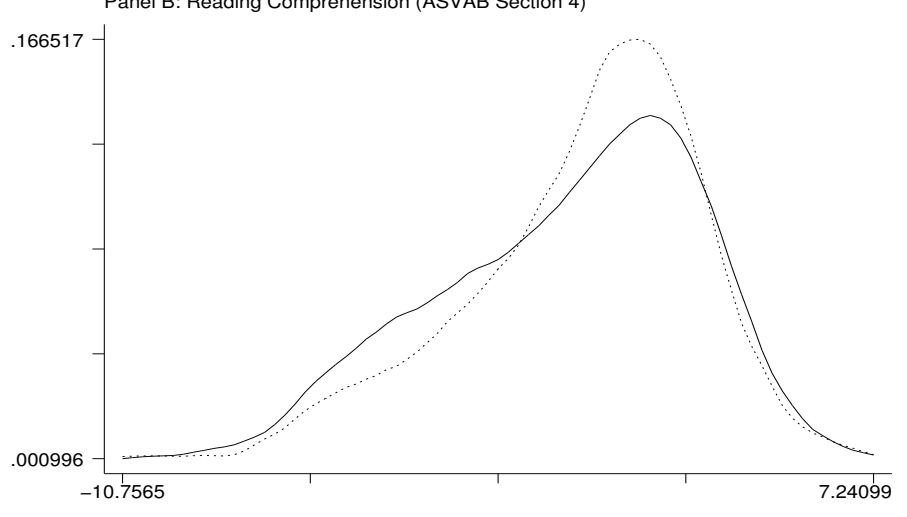

Panel D: Coding Speed (ASVAB Section 6)

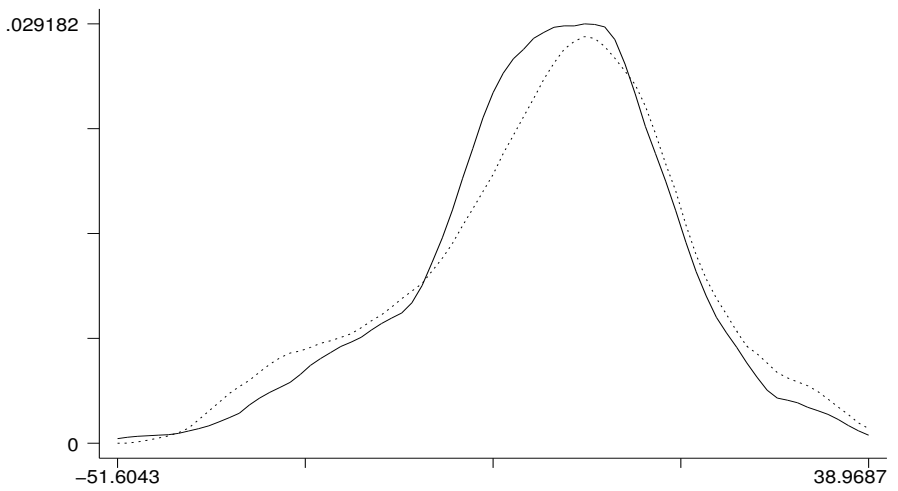

Solid line: Foreign Language Spoken at Home

Dashed line: English Spoken at Home

Notes: Data are from the NLSY-1979. Sample size is 751 (composed of children who were born in the US with at least one foreign-born parent and with nonmissing ASVAB scores). Displayed in each panel is the kernel density estimate for the indicated ASVAB subtest, decomposed by whether a foreign language was spoken at the respondent's childhood home (solid line for yes, dashed line for no). The residualized ASVAB scores are computed from a regression of the raw score on quadratics in the highest grade completed for each parent, dummies if the parental education variables are missing, and dummies for Black and year of birth. The mean differences in ASVAB subtests between the two groups (measured by including the foreign-language-at-home indicator variable in the regression) in Panels $A-D$ have $p$-values of $0.059,0.120,0.139$, and 0.783 , respectively. 
Table 1. Descriptive Statistics

\begin{tabular}{|c|c|c|c|c|c|c|}
\hline & \multicolumn{3}{|c|}{ Parent from non-English-speaking ctries } & \multicolumn{3}{|c|}{ Parent from English-speaking ctries } \\
\hline & $\begin{array}{l}\text { Total } \\
(1)\end{array}$ & $\begin{array}{c}\text { Arrived } \\
\text { aged 0-9 } \\
(2)\end{array}$ & $\begin{array}{c}\text { Arrived } \\
\text { aged } 10-17 \\
\text { (3) }\end{array}$ & $\begin{array}{c}\text { Total } \\
(4)\end{array}$ & $\begin{array}{c}\text { Arrived } \\
\text { aged 0-9 } \\
(5)\end{array}$ & $\begin{array}{c}\text { Arrived } \\
\text { aged } 10-17 \\
(6)\end{array}$ \\
\hline \multicolumn{7}{|c|}{ A. Parent's Characteristics } \\
\hline $\begin{array}{l}\text { English ordinal measure } \\
\text { (scale of } 0 \text { to } 3,3=\text { best) }\end{array}$ & $\begin{array}{c}2.4006 \\
(0.8658)\end{array}$ & $\begin{array}{l}2.8676 \\
(0.4236)\end{array}$ & $\begin{array}{c}2.0680 \\
(0.9432)\end{array}$ & $\begin{array}{c}2.9840 \\
(0.1481)\end{array}$ & $\begin{array}{c}2.9865 \\
(0.1333)\end{array}$ & $\begin{array}{c}2.9802 \\
(0.1689)\end{array}$ \\
\hline Age & $\begin{array}{l}37.0198 \\
(6.4033)\end{array}$ & $\begin{array}{l}37.8836 \\
(6.5726)\end{array}$ & $\begin{array}{l}36.4047 \\
(6.2072)\end{array}$ & $\begin{array}{l}39.3522 \\
(6.0605)\end{array}$ & $\begin{array}{l}40.0481 \\
(5.8508)\end{array}$ & $\begin{array}{l}38.2514 \\
(6.2216)\end{array}$ \\
\hline Female & $\begin{array}{c}0.6375 \\
(0.4807)\end{array}$ & $\begin{array}{c}0.6346 \\
(0.4815)\end{array}$ & $\begin{array}{c}0.6395 \\
(0.4802)\end{array}$ & $\begin{array}{c}0.6347 \\
(0.4815)\end{array}$ & $\begin{array}{c}0.5905 \\
(0.4918)\end{array}$ & $\begin{array}{c}0.7047 \\
(0.4562)\end{array}$ \\
\hline White & $\begin{array}{c}0.5120 \\
(0.4999)\end{array}$ & $\begin{array}{c}0.6356 \\
(0.4813)\end{array}$ & $\begin{array}{c}0.4239 \\
(0.4942)\end{array}$ & $\begin{array}{c}0.6299 \\
(0.4828)\end{array}$ & $\begin{array}{c}0.8155 \\
(0.3879)\end{array}$ & $\begin{array}{c}0.3364 \\
(0.4725)\end{array}$ \\
\hline Black & $\begin{array}{c}0.0257 \\
(0.1581)\end{array}$ & $\begin{array}{c}0.0280 \\
(0.1649)\end{array}$ & $\begin{array}{c}0.0240 \\
(0.1530)\end{array}$ & $\begin{array}{c}0.2918 \\
(0.4546)\end{array}$ & $\begin{array}{c}0.1409 \\
(0.3480)\end{array}$ & $\begin{array}{c}0.5304 \\
(0.4991)\end{array}$ \\
\hline Asian/Pacific Islander & $\begin{array}{c}0.0744 \\
(0.2625)\end{array}$ & $\begin{array}{c}0.0454 \\
(0.2081)\end{array}$ & $\begin{array}{c}0.0951 \\
(0.2934)\end{array}$ & $\begin{array}{c}0.0230 \\
(0.1500)\end{array}$ & $\begin{array}{c}0.0093 \\
(0.0960)\end{array}$ & $\begin{array}{c}0.0447 \\
(0.2067)\end{array}$ \\
\hline Other single race & $\begin{array}{c}0.3353 \\
(0.4721)\end{array}$ & $\begin{array}{c}0.2421 \\
(0.4284)\end{array}$ & $\begin{array}{c}0.4017 \\
(0.4902)\end{array}$ & $\begin{array}{c}0.0171 \\
(0.1297)\end{array}$ & $\begin{array}{c}0.0105 \\
(0.1017)\end{array}$ & $\begin{array}{c}0.0276 \\
(0.1639)\end{array}$ \\
\hline Multiracial & $\begin{array}{c}0.0510 \\
(0.2200)\end{array}$ & $\begin{array}{c}0.0489 \\
(0.2156)\end{array}$ & $\begin{array}{c}0.0552 \\
(0.2284)\end{array}$ & $\begin{array}{c}0.0360 \\
(0.1864)\end{array}$ & $\begin{array}{c}0.0238 \\
(0.1525)\end{array}$ & $\begin{array}{c}0.0608 \\
(0.2390)\end{array}$ \\
\hline Hispanic & $\begin{array}{c}0.6590 \\
(0.4741)\end{array}$ & $\begin{array}{c}0.5119 \\
(0.4999)\end{array}$ & $\begin{array}{c}0.7637 \\
(0.4248)\end{array}$ & $\begin{array}{c}0.0129 \\
(0.1129)\end{array}$ & $\begin{array}{c}0.0139 \\
(0.1171)\end{array}$ & $\begin{array}{c}0.0113 \\
(0.1058)\end{array}$ \\
\hline \multicolumn{7}{|c|}{ B. Child's Characteristics } \\
\hline Age & $\begin{array}{l}10.2227 \\
(3.5988)\end{array}$ & $\begin{array}{l}10.3692 \\
(3.6198)\end{array}$ & $\begin{array}{l}10.1184 \\
(3.5801)\end{array}$ & $\begin{array}{l}10.6310 \\
(3.6640)\end{array}$ & $\begin{array}{l}10.7867 \\
(3.6565)\end{array}$ & $\begin{array}{l}10.3847 \\
(3.6625)\end{array}$ \\
\hline Female & $\begin{array}{c}0.4850 \\
(0.4998)\end{array}$ & $\begin{array}{c}0.4858 \\
(0.4998)\end{array}$ & $\begin{array}{c}0.4844 \\
(0.4998)\end{array}$ & $\begin{array}{c}0.4867 \\
(0.4998)\end{array}$ & $\begin{array}{c}0.4925 \\
(0.5000)\end{array}$ & $\begin{array}{c}0.4774 \\
(0.4995)\end{array}$ \\
\hline $\begin{array}{l}\text { English ordinal measure } \\
\text { (scale of } 0 \text { to } 3,3=\text { best) }\end{array}$ & $\begin{array}{c}2.7281 \\
(0.5940)\end{array}$ & $\begin{array}{c}2.8482 \\
(0.4595)\end{array}$ & $\begin{array}{c}2.6426 \\
(0.6604)\end{array}$ & $\begin{array}{c}2.9823 \\
(0.1737)\end{array}$ & $\begin{array}{l}2.9846 \\
(0.1577)\end{array}$ & $\begin{array}{c}2.9786 \\
(0.1964)\end{array}$ \\
\hline Number of observations & 148,039 & 61,683 & 86,356 & 16,520 & 10,265 & 6,255 \\
\hline \multicolumn{7}{|c|}{ C. Child Educational Outcomes for Restricted Ages } \\
\hline $\begin{array}{l}\text { Dropped out of high school } \\
\text { for children age } 15-17\end{array}$ & $\begin{array}{c}0.0232 \\
(0.1507)\end{array}$ & $\begin{array}{c}0.0203 \\
(0.1410)\end{array}$ & $\begin{array}{c}0.0257 \\
(0.1581)\end{array}$ & $\begin{array}{c}0.0142 \\
(0.1181)\end{array}$ & $\begin{array}{c}0.0160 \\
(0.1256)\end{array}$ & $\begin{array}{c}0.0106 \\
(0.1023)\end{array}$ \\
\hline $\begin{array}{l}\text { Below age-appropriate } \\
\text { grade for children age } 15-17\end{array}$ & $\begin{array}{c}0.0713 \\
(0.2574)\end{array}$ & $\begin{array}{c}0.0619 \\
(0.2410)\end{array}$ & $\begin{array}{c}0.0791 \\
(0.2699)\end{array}$ & $\begin{array}{c}0.0515 \\
(0.2210)\end{array}$ & $\begin{array}{c}0.0525 \\
(0.2232)\end{array}$ & $\begin{array}{c}0.0495 \\
(0.2170)\end{array}$ \\
\hline $\begin{array}{l}\text { Attending school } \\
\text { for children age 3-7 }\end{array}$ & $\begin{array}{c}0.7293 \\
(0.4443)\end{array}$ & $\begin{array}{c}0.7550 \\
(0.4301)\end{array}$ & $\begin{array}{c}0.7119 \\
(0.4529)\end{array}$ & $\begin{array}{c}0.8071 \\
(0.3946)\end{array}$ & $\begin{array}{c}0.8044 \\
(0.3967)\end{array}$ & $\begin{array}{c}0.8107 \\
(0.3918)\end{array}$ \\
\hline $\begin{array}{l}\text { 6-year-old attending } \\
\text { kindergarten or higher }\end{array}$ & $\begin{array}{c}0.9812 \\
(0.1358)\end{array}$ & $\begin{array}{c}0.9815 \\
(0.1349)\end{array}$ & $\begin{array}{c}0.9811 \\
(0.1363)\end{array}$ & $\begin{array}{c}0.9868 \\
(0.1140)\end{array}$ & $\begin{array}{c}0.9885 \\
(0.1065)\end{array}$ & $\begin{array}{c}0.9843 \\
(0.1244)\end{array}$ \\
\hline $\begin{array}{l}\text { 7-year-old attending } \\
\text { first grade or higher }\end{array}$ & $\begin{array}{c}0.9650 \\
(0.1837)\end{array}$ & $\begin{array}{c}0.9668 \\
(0.1791)\end{array}$ & $\begin{array}{c}0.9638 \\
(0.1868)\end{array}$ & $\begin{array}{c}0.9629 \\
(0.1891)\end{array}$ & $\begin{array}{c}0.9559 \\
(0.2054)\end{array}$ & $\begin{array}{c}0.9725 \\
(0.1637)\end{array}$ \\
\hline
\end{tabular}

Notes: The sample consists of children aged 5-17 from the 2000 IPUMS who are born in the US, live with at least one biological parent aged 25-55 who immigrated to the US before age 18, and have nonmissing English variable for both self and parent (total number of observations is 164,559). There are fewer observations for the child educational outcomes because they are calculated over a narrower range of children's ages. Statistics are weighted by child-level IPUMS weights. The English-speaking ability ordinal measure is defined as: $0=$ no English, $1=$ not well, $2=$ well, and $3=$ very well. 
Table 2. Impact on English-Language Skills

\begin{tabular}{|c|c|c|c|c|c|c|}
\hline & \multirow{2}{*}{$\begin{array}{c}\text { First-stage Equation } \\
\text { Parental English } \\
\text { OLS } \\
(1) \\
\end{array}$} & \multirow{2}{*}{$\begin{array}{c}\begin{array}{c}\text { Reduced-form Equation } \\
\text { Child English }\end{array} \\
\text { OLS } \\
\text { (2) }\end{array}$} & \multicolumn{4}{|c|}{$\begin{array}{l}\text { Second-stage Equation } \\
\text { Child English }\end{array}$} \\
\hline & & & $\begin{array}{r}2 S L S \\
(3) \\
\end{array}$ & & $\begin{array}{c}2 S L S \\
(4)\end{array}$ & $\begin{array}{c}\text { OLS } \\
(5)\end{array}$ \\
\hline Parental English & & & $\begin{array}{c}0.1692 \\
(0.0211)\end{array}$ & *** & $\begin{array}{l}0.1611^{* * *} \\
(0.0198)\end{array}$ & $\begin{array}{l}0.1849^{* * *} \\
(0.0092)\end{array}$ \\
\hline $\begin{array}{l}\text { (Parent arrived young (age 0-9)) } \times \\
\text { (Parent is from non-English- } \\
\text { speaking country of birth) }\end{array}$ & $\begin{array}{l}0.5808^{* * *} \\
(0.1409)\end{array}$ & $\begin{array}{l}0.0983^{* * *} \\
(0.0326)\end{array}$ & & & & \\
\hline Parent is Hispanic & $\begin{array}{l}-0.0504^{* *} \\
(0.0250)\end{array}$ & $\begin{array}{l}-0.06022^{\star \star \star} \\
(0.0166)\end{array}$ & $\begin{array}{l}-0.0516 \\
(0.0166)\end{array}$ & *** & $\begin{array}{l}-0.05222^{* * *} \\
(0.0165)\end{array}$ & $\begin{array}{l}-0.0506 \quad * * * \\
(0.0159)\end{array}$ \\
\hline \multicolumn{7}{|l|}{$\begin{array}{l}\text { Parent race dummies } \\
\text { (relative to White) }\end{array}$} \\
\hline Black & $\begin{array}{l}0.0494^{* * *} \\
(0.0118)\end{array}$ & $\begin{array}{l}0.0228 \\
(0.0077)\end{array}$ & $\begin{array}{c}0.0144 \\
(0.0073)\end{array}$ & ** & $\begin{array}{l}0.01499^{* *} \\
(0.0072)\end{array}$ & $\begin{array}{l}0.0133 \\
(0.0071)\end{array}$ \\
\hline Asian and Pacific Islander & $\begin{array}{c}0.0361 \\
(0.0504)\end{array}$ & $\begin{array}{l}-0.0418 \\
(0.0258)\end{array}$ & $\begin{array}{l}-0.0479 \\
(0.0194)\end{array}$ & ** & $\begin{array}{l}-0.04766^{* *} \\
(0.0195)\end{array}$ & $\begin{array}{l}-0.0485 \\
(0.0187)\end{array}$ \\
\hline Multiracial & $\begin{array}{c}0.0197 \\
(0.0136)\end{array}$ & $\begin{array}{l}0.0284^{* * *} \\
(0.0072)\end{array}$ & $\begin{array}{c}0.0251 \\
(0.0065)\end{array}$ & *** & $\begin{array}{l}0.0252^{* * *} \\
(0.0065)\end{array}$ & $\begin{array}{l}0.0247 \\
(0.0066)\end{array}$ \\
\hline Other & $\begin{array}{l}-0.0045 \\
(0.0095)\end{array}$ & $\begin{array}{c}0.0122 \\
(0.0083)\end{array}$ & $\begin{array}{c}0.0129 \\
(0.0070)\end{array}$ & & $\begin{array}{l}0.0129 \\
(0.0071)\end{array}$ & $\begin{array}{l}0.0130 \\
(0.0069)\end{array}$ \\
\hline Parental age and sex dummies & Yes & Yes & Yes & & Yes & Yes \\
\hline Child age and sex dummies & Yes & Yes & Yes & & Yes & Yes \\
\hline Parental age-at-arrival dummies & Yes & Yes & Yes & & Yes & Yes \\
\hline Parental country-of-birth dummies & Yes & Yes & Yes & & Yes & Yes \\
\hline Adjusted R-squared & 0.387 & 0.158 & & & & 0.204 \\
\hline $\begin{array}{c}\text { F statistic for test that instruments } \\
\text { are jointly significant [p-value] }\end{array}$ & & & $\begin{array}{c}17.0 \\
{[<0.0001]}\end{array}$ & & $\begin{array}{r}66.9 \\
{[<0.0001]}\end{array}$ & \\
\hline $\begin{array}{l}\text { Hansen } \mathrm{J} \text { statistic for test of } \\
\text { overidentification of all } \\
\text { instruments [p-value] }\end{array}$ & & & & & $\begin{array}{r}9.4 \\
{[0.8982]}\end{array}$ & \\
\hline
\end{tabular}

Notes: The sample is as described in Table 1 notes. In Column 3, the identifying instrument is (parent arrived young) $\times$ (parent is from non. English-speaking country). In Column 4, the identifying instruments are interactions between dummies for parental age at arrival and dummy for parent being born in a non-English-speaking country (omitted category is the interaction involving parent arriving at age 0 ). Each column is from a separate regression that is weighted by child-level IPUMS weights and contains dummies for the country of birth, age at arrival, age, sex, race, and Hispanic status of the parent who is the childhood immigrant, and dummies for the age and sex of the child. The country-of-birth dummies are based on IPUMS detailed birthplace codes. Robust standard errors adjusted for clustering by parental country of birth are shown in parentheses. Asterisks denote significance levels $\left({ }^{*}=.10,{ }^{* *}=.05,{ }^{* * *}=.01\right)$. 
Table 3. Effect of Parental English on Child's Early Educational Outcomes

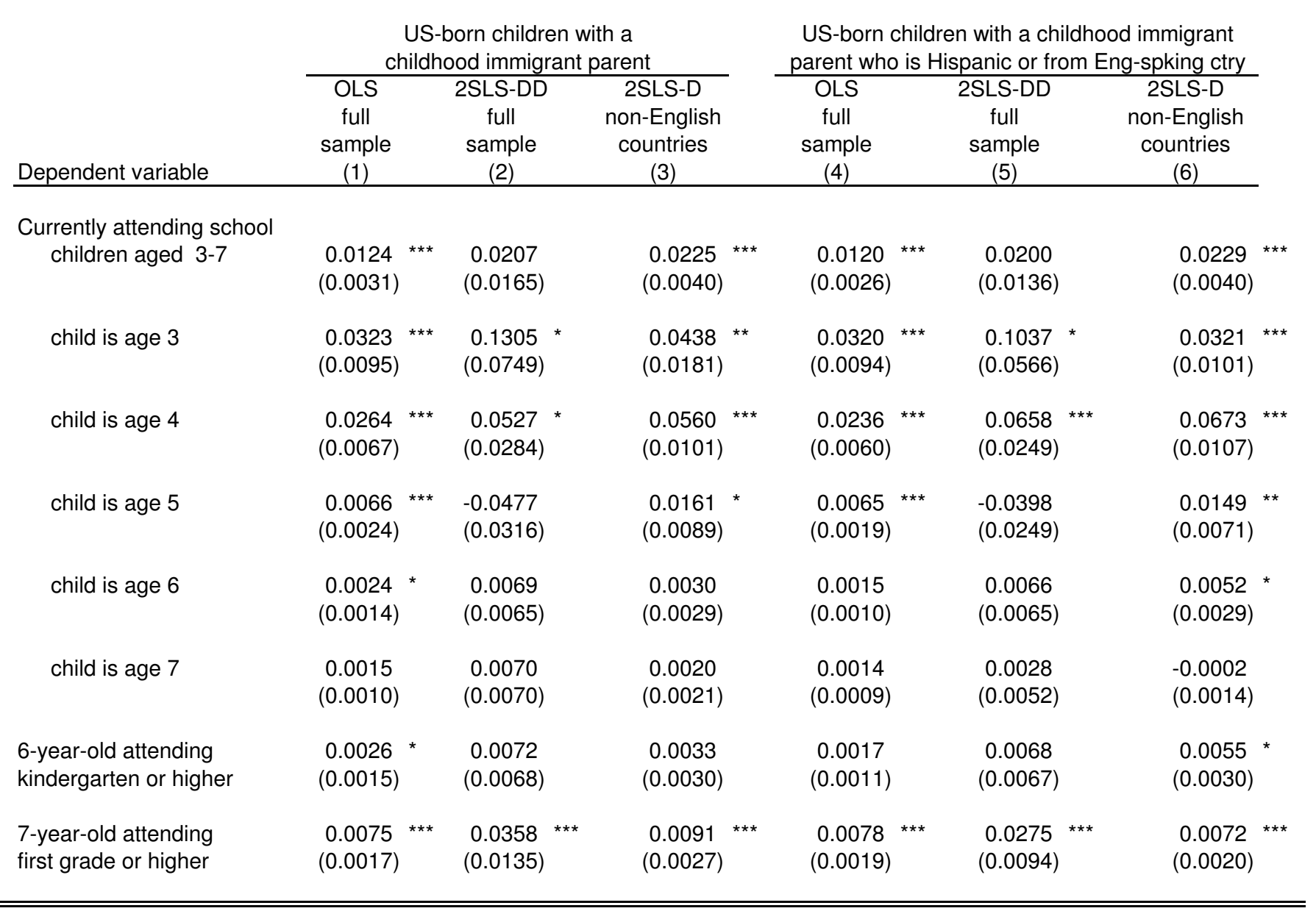

Notes: The sample consists of children aged 3-7 from the 2000 IPUMS who are born in the US, live with at least one biological parent aged 25-55 who immigrated to the US before age 18, have nonmissing English variable for parent, and have nonmissing school attendance variable for self. Each cell is from a separate regression that is weighted by child-level IPUMS weights and contains dummies for the country of birth, age, sex, race, and Hispanic status of the parent who is the childhood immigrant, and dummies for the age and sex of the child; Columns 1,2, 4, and 5 additionally have dummies for parental age at arrival. Columns 1 and 2 report the coefficient for parental English when the child education equation is estimated using the full sample of children using OLS and 2SLS (with the interactions between dummies for parental age at arrival and dummy for parent being born in a non-English-speaking country as the identifying instruments), respectively. Column 3 shows the coefficient for parental English from estimating the child education equation using the subsample of children whose parent is from a non-English-speaking country using 2SLS (with dummies for parental age at arrival as the identifying instruments). Columns 4-6 parallel Columns 1-3, but data is restricted to children whose parent is either Hispanic or from an English-speaking country. Robust standard errors adjusted for clustering by parental country of birth are shown in parentheses. Asterisks denote significance levels $\left({ }^{*}=.10,{ }^{* *}=.05,{ }^{* * *}=.01\right)$. 
Table 4. Effect of Parental English on Child's Longer-Run Educational Outcomes

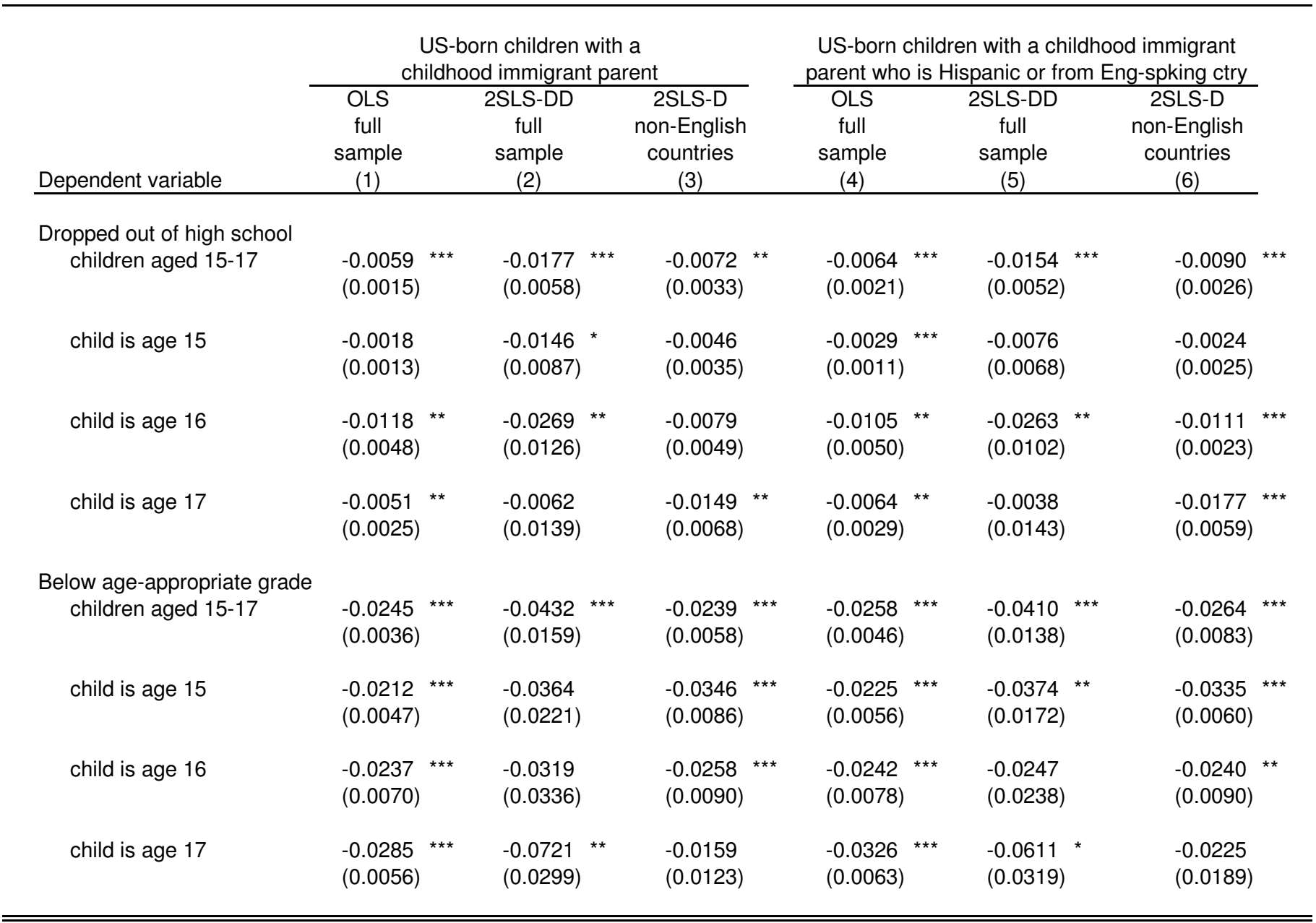

Notes: The sample is as described in Table 1 notes with the additional restrictions that child is aged 15-17 and has nonmissing school attendance and school attainment variables. Each cell is from a separate regression that is weighted by child-level IPUMS weights and contains dummies for the country of birth, age, sex, race, and Hispanic status of the parent who is the childhood immigrant, and dummies for the age and sex of the child; Columns 1,2, 4, and 5 additionally have dummies for parental age at arrival. Columns 1 and 2 report the coefficient for parental English when the child education equation is estimated using the full sample of children using OLS and 2SLS (with the interactions between dummies for parental age at arrival and dummy for parent being born in a non-Englishspeaking country as the identifying instruments), respectively. Column 3 shows the coefficient for parental English from estimating the child education equation using the subsample of children whose parent is from a non-English-speaking country using 2SLS (with dummies for parental age at arrival as the identifying instruments). Columns 4-6 parallel Columns 1-3, but data is restricted to children whose parent is either Hispanic or from an English-speaking country. Robust standard errors adjusted for clustering by parental country of birth are shown in parentheses. Asterisks denote significance levels $\left({ }^{*}=.10,{ }^{* *}=.05,{ }^{* * *}=.01\right)$. 
Table 5. 2SLS Estimates of the Effect of Parental English on Child's Outcomes, Alternative Samples and Specifications

\begin{tabular}{|c|c|c|c|c|c|c|c|c|c|c|c|c|c|c|c|}
\hline & \multicolumn{2}{|c|}{$\begin{array}{l}\text { English, } \\
\text { children 5-11 }\end{array}$} & & \multicolumn{2}{|c|}{$\begin{array}{c}\text { Attends school, } \\
\text { children 3-4 } \\
\end{array}$} & & \multicolumn{3}{|c|}{$\begin{array}{l}\text { 6-yr-old attends } \mathrm{K}_{+} \\
\text {or 7-yr-old attends } 1 \text { st+ }\end{array}$} & \multicolumn{3}{|c|}{$\begin{array}{c}\text { Below age-appropriate } \\
\text { grade, children age 15-17 } \\
\end{array}$} & \multicolumn{3}{|c|}{$\begin{array}{l}\text { Dropped out of h.s., } \\
\text { children age 15-17 }\end{array}$} \\
\hline & $\begin{array}{c}\text { 2SLS-DD } \\
\text { full } \\
\text { sample } \\
(1) \\
\end{array}$ & $\begin{array}{c}\text { 2SLS-D } \\
\text { non-English } \\
\text { countries } \\
(2) \\
\end{array}$ & & $\begin{array}{l}\text { 2SLS-DD } \\
\text { full } \\
\text { sample } \\
(3) \\
\end{array}$ & $\begin{array}{c}\text { 2SLS-D } \\
\text { non-English } \\
\text { countries } \\
(4) \\
\end{array}$ & & $\begin{array}{l}\text { 2SLS-DD } \\
\text { full } \\
\text { sample } \\
(5) \\
\end{array}$ & $\begin{array}{c}\text { 2SLS-D } \\
\text { non-English } \\
\text { countries } \\
(6) \\
\end{array}$ & & $\begin{array}{l}\text { 2SLS-DD } \\
\text { full } \\
\text { sample } \\
(7) \\
\end{array}$ & $\begin{array}{c}\text { 2SLS-D } \\
\text { non-English } \\
\text { countries } \\
(8) \\
\end{array}$ & & $\begin{array}{l}\text { 2SLS-DD } \\
\text { full } \\
\text { sample } \\
(9) \\
\end{array}$ & $\begin{array}{c}\text { 2SLS-D } \\
\text { non-English } \\
\text { countries } \\
(10) \\
\end{array}$ & \\
\hline A. Base sample and specification & $\begin{array}{l}0.2387^{* * *} \\
(0.0184)\end{array}$ & $\begin{array}{c}0.2378 \\
(0.0143)\end{array}$ & *** & $\begin{array}{l}0.0939 \\
(0.0384)\end{array}$ & $\begin{array}{c}0.0502 \\
(0.0091)\end{array}$ & *** & $\begin{array}{l}0.0193 \\
(0.0079)\end{array}$ & $\begin{array}{c}0.0059 \\
(0.0020)\end{array}$ & *** & $\begin{array}{l}-0.04322^{* \star *} \\
(0.0159)\end{array}$ & $\begin{array}{l}-0.0239 \\
(0.0058)\end{array}$ & *** & $\begin{array}{l}-0.0177^{* \star *} \\
(0.0058)\end{array}$ & $\begin{array}{l}-0.0072 \\
(0.0033)\end{array}$ & ** \\
\hline $\begin{array}{l}\text { B. Only parents arriving in the US } \\
\text { at age } 0-15 \text { (drop older arrivers) }\end{array}$ & $\begin{array}{l}0.26811^{* * *} \\
(0.0162)\end{array}$ & $\begin{array}{c}0.2472 \\
(0.0107)\end{array}$ & *** & $\begin{array}{l}0.1259 \\
(0.0516)\end{array}$ & $\begin{array}{c}0.0844 \\
(0.0187)\end{array}$ & *** & $\begin{array}{c}0.0032 \\
(0.0145)\end{array}$ & $\begin{array}{c}0.0046 \\
(0.0023)\end{array}$ & ** & $\begin{array}{l}-0.0337 \\
(0.0168)\end{array}$ & $\begin{array}{l}-0.0304 \\
(0.0078)\end{array}$ & *** & $\begin{array}{l}-0.0176 \quad * * * \\
(0.0055)\end{array}$ & $\begin{array}{l}-0.0118 \\
(0.0029)\end{array}$ & *** \\
\hline $\begin{array}{l}\text { C. Control for } \max (0 \text {, parental age at } \\
\text { arrival }-6) \times \ln (\text { per capita PPP GDP } \\
\text { in parental country of birth) }\end{array}$ & $\begin{array}{l}0.2345^{* * *} \\
(0.0199)\end{array}$ & $\begin{array}{c}0.2415 \\
(0.0120)\end{array}$ & *** & $\begin{array}{l}0.0793 \quad \text { *** } \\
(0.0290)\end{array}$ & $\begin{array}{c}0.0444 \\
(0.0051)\end{array}$ & *** & $\begin{array}{l}0.0192 \\
(0.0087)\end{array}$ & $\begin{array}{c}0.0070 \\
(0.0022)\end{array}$ & *** & $\begin{array}{l}-0.0390^{* * *} \\
(0.0144)\end{array}$ & $\begin{array}{l}-0.0196 \\
(0.0032)\end{array}$ & *** & $\begin{array}{l}-0.0164^{* * *} \\
(0.0057)\end{array}$ & $\begin{array}{l}-0.0075 \\
(0.0031)\end{array}$ & ** \\
\hline $\begin{array}{l}\text { D. Control for } \max (0 \text {, parental age at } \\
\text { arrival }-6) \times \ln (\text { school expenditures } \\
\text { per child in parental country of birth) }\end{array}$ & $\begin{array}{l}0.2538 \\
(0.0177)\end{array}$ & $\begin{array}{c}0.2534 \\
(0.0054)\end{array}$ & *** & $\begin{array}{c}0.0788 \\
(0.0573)\end{array}$ & $\begin{array}{c}0.0469 \\
(0.0075)\end{array}$ & *** & $\begin{array}{l}0.0250 \\
(0.0118)\end{array}$ & $\begin{array}{c}0.0041 \\
(0.0018)\end{array}$ & ** & $\begin{array}{l}-0.0548 \\
(0.0363)\end{array}$ & $\begin{array}{l}-0.0209 \\
(0.0051)\end{array}$ & *** & $\begin{array}{l}-0.0242 \\
(0.0155)\end{array}$ & $\begin{array}{l}-0.0092 \\
(0.0029)\end{array}$ & *** \\
\hline $\begin{array}{l}\text { E. Control for } \max (0 \text {, parental age at } \\
\text { arrival }-6) \times \ln (\text { teacher-pupil ratio } \\
\text { in parental country of birth) }\end{array}$ & $\begin{array}{l}0.2313^{* * *} \\
(0.0163)\end{array}$ & $\begin{array}{c}0.2493 \\
(0.0064)\end{array}$ & *** & $\begin{array}{l}0.0966 \\
(0.0540)\end{array}$ & $\begin{array}{c}0.0483 \\
(0.0077)\end{array}$ & *** & $\begin{array}{l}0.0274^{* * *} \\
(0.0073)\end{array}$ & $\begin{array}{c}0.0050 \\
(0.0019)\end{array}$ & *** & $\begin{array}{l}-0.0563 \\
(0.0296)\end{array}$ & $\begin{array}{l}-0.0195 \\
(0.0048)\end{array}$ & *** & $\begin{array}{l}-0.02444^{* *} \\
(0.0106)\end{array}$ & $\begin{array}{l}-0.0080 \\
(0.0029)\end{array}$ & *** \\
\hline $\begin{array}{l}\text { F. Only parents from below-median-GDP } \\
\text { country of birth }\end{array}$ & $\begin{array}{l}0.2428 \\
(0.1248)\end{array}$ & $\begin{array}{c}0.2482 \\
(0.0061)\end{array}$ & *** & $\begin{array}{l}0.0598 \\
(0.0319)\end{array}$ & $\begin{array}{c}0.0489 \\
(0.0064)\end{array}$ & *** & $\begin{array}{l}0.02799^{* * *} \\
(0.0092)\end{array}$ & $\begin{array}{l}0.0064 \\
(0.0015)\end{array}$ & *** & $\begin{array}{l}-0.0265 \\
(0.0179)\end{array}$ & $\begin{array}{l}-0.0243 \\
(0.0058)\end{array}$ & *** & $\begin{array}{l}-0.02311^{* * *} \\
(0.0051)\end{array}$ & $\begin{array}{l}-0.0116 \\
(0.0021)\end{array}$ & *** \\
\hline $\begin{array}{l}\text { G. Only parents from above-median-GDP } \\
\text { country of birth }\end{array}$ & $\begin{array}{l}0.1419 \\
(0.0568)\end{array}$ & $\begin{array}{c}0.1699 \\
(0.0647)\end{array}$ & ** & $\begin{array}{c}0.1619 \\
(0.1492)\end{array}$ & $\begin{array}{c}0.0078 \\
(0.0614)\end{array}$ & & $\begin{array}{c}0.0301 \\
(0.0345)\end{array}$ & $\begin{array}{c}0.0338 \\
(0.0195)\end{array}$ & & $\begin{array}{l}-0.0562 \\
(0.0282)\end{array}$ & $\begin{array}{c}0.0033 \\
(0.0245)\end{array}$ & & $\begin{array}{l}-0.0170 \\
(0.0154)\end{array}$ & $\begin{array}{l}0.0084 \\
(0.0077)\end{array}$ & \\
\hline H. Exclude parents from Canada & $\begin{array}{l}0.23488^{* * *} \\
(0.0187)\end{array}$ & $\begin{array}{l}\text { Identical to } \\
\text { Row A }\end{array}$ & & $\begin{array}{l}0.0657 \\
(0.0340)\end{array}$ & $\begin{array}{l}\text { Identical to } \\
\text { Row A }\end{array}$ & & $\begin{array}{l}0.0237^{* * *} \\
(0.0086)\end{array}$ & $\begin{array}{l}\text { Identical to } \\
\text { Row A }\end{array}$ & & $\begin{array}{l}-0.0331 \\
(0.0177)\end{array}$ & $\begin{array}{l}\text { Identical to } \\
\text { Row A }\end{array}$ & & $\begin{array}{l}-0.0116 \\
(0.0056)\end{array}$ & $\begin{array}{l}\text { Identical to } \\
\text { Row A }\end{array}$ & \\
\hline I. Only parents from Caribbean & $\begin{array}{l}0.0518 \\
(0.0248)\end{array}$ & $\begin{array}{c}0.0770 \\
(0.0131)\end{array}$ & ${ }^{\star \star \star}$ & $\begin{array}{l}0.1569 \\
(0.0814)\end{array}$ & $\begin{array}{c}0.0912 \\
(0.0577)\end{array}$ & & $\begin{array}{c}0.0360 \\
(0.0302)\end{array}$ & $\begin{array}{c}0.0159 \\
(0.0210)\end{array}$ & & $\begin{array}{l}-0.0096 \\
(0.0423)\end{array}$ & $\begin{array}{l}-0.0622 \\
(0.0272)\end{array}$ & & $\begin{array}{l}-0.0081 \\
(0.0105)\end{array}$ & $\begin{array}{l}-0.0037 \\
(0.0041)\end{array}$ & \\
\hline J. Only parents from Europe or Canada & $\begin{array}{c}0.0788 \\
(0.0721)\end{array}$ & $\begin{array}{c}0.1374 \\
(0.0675)\end{array}$ & ** & $\begin{array}{c}0.1412 \\
(0.2510)\end{array}$ & $\begin{array}{c}0.0405 \\
(0.1020)\end{array}$ & & $\begin{array}{c}0.0289 \\
(0.0502)\end{array}$ & $\begin{array}{c}0.0222 \\
(0.0263)\end{array}$ & & $\begin{array}{l}-0.0857 \text { ** } \\
(0.0370)\end{array}$ & $\begin{array}{c}0.0164 \\
(0.0233)\end{array}$ & & $\begin{array}{l}-0.0571 \\
(0.0285)\end{array}$ & $\begin{array}{c}0.0240 \\
(0.0182)\end{array}$ & \\
\hline $\begin{array}{l}\text { K. Only children whose parents had them } \\
\geq 10 \text { years after arriving in the US }\end{array}$ & $\begin{array}{l}0.24888^{* * *} \\
(0.0238)\end{array}$ & $\begin{array}{c}0.2597 \\
(0.0175)\end{array}$ & *** & $\begin{array}{l}0.1187^{* *} \\
(0.0476)\end{array}$ & $\begin{array}{c}0.0782 \\
(0.0167)\end{array}$ & $* * *$ & $\begin{array}{l}0.0181 \\
(0.0106)\end{array}$ * & $\begin{array}{c}0.0096 \\
(0.0036)\end{array}$ & *** & $\begin{array}{l}-0.0108 \\
(0.0251)\end{array}$ & $\begin{array}{l}-0.0192 \\
(0.0068)\end{array}$ & *** & $\begin{array}{l}-0.01811^{* *} \\
(0.0071)\end{array}$ & $\begin{array}{l}-0.0102 \\
(0.0045)\end{array}$ & ** \\
\hline
\end{tabular}

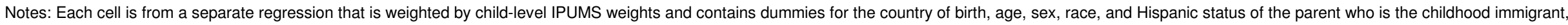

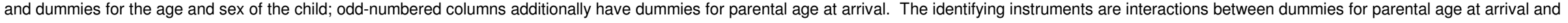

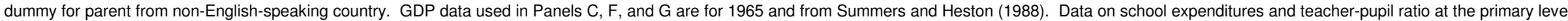

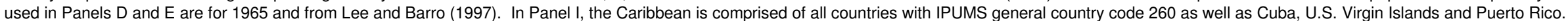
In Panel J, only countries with IPUMS general country code 150 (Canada) or 400-499 (European continent) are included. Robust standard errors adjusted for clustering by parental country of birth are shown in parentheses. Asterisks denote significance levels $\left({ }^{*}=.10,{ }^{* *}=.05,{ }^{* * *}=.01\right)$. 
Table 6. Potential Channels for the Effect of Parental English on Child's Outcomes

\begin{tabular}{|c|c|c|c|c|c|c|c|c|c|c|c|c|}
\hline & \multicolumn{3}{|c|}{$\begin{array}{l}\text { English, } \\
\text { children 5-11 }\end{array}$} & \multicolumn{3}{|c|}{$\begin{array}{l}\text { Attends school, } \\
\text { children 3-4 }\end{array}$} & \multicolumn{2}{|c|}{$\begin{array}{l}\text { 6-yr-old attends } \mathrm{K}_{+} \\
\text {or } 7 \text {-yr-old attends } 1 \text { st+ }\end{array}$} & \multicolumn{2}{|c|}{$\begin{array}{l}\text { Below age-appropriate } \\
\text { grade, children age 15-17 }\end{array}$} & \multicolumn{2}{|c|}{$\begin{array}{l}\text { Dropped out of h.s., } \\
\text { children age } 15-17\end{array}$} \\
\hline & $\begin{array}{c}\text { 2SLS-DD } \\
\text { full } \\
\text { sample } \\
(1) \\
\end{array}$ & $\begin{array}{c}\text { 2SLS-D } \\
\text { non-English } \\
\text { countries } \\
(2) \\
\end{array}$ & & $\begin{array}{l}\text { 2SLS-DD } \\
\text { full } \\
\text { sample } \\
\text { (3) } \\
\end{array}$ & $\begin{array}{c}\text { 2SLS-D } \\
\text { non-English } \\
\text { countries } \\
(4) \\
\end{array}$ & & $\begin{array}{l}\text { 2SLS-DD } \\
\text { full } \\
\text { sample } \\
\text { (5) }\end{array}$ & $\begin{array}{c}\text { 2SLS-D } \\
\text { non-English } \\
\text { countries } \\
(6) \\
\end{array}$ & $\begin{array}{l}\text { 2SLS-DD } \\
\text { full } \\
\text { sample } \\
\text { (7) }\end{array}$ & $\begin{array}{c}2 \text { SLS-D } \\
\text { non-English } \\
\text { countries } \\
(8) \\
\end{array}$ & $\begin{array}{l}\text { 2SLS-DD } \\
\text { full } \\
\text { sample } \\
(9) \\
\end{array}$ & $\begin{array}{c}2 \text { SLS-D } \\
\text { non-English } \\
\text { countries } \\
(10) \\
\end{array}$ \\
\hline A. Base sample and specification & $\begin{array}{l}0.2387^{* * *} \\
(0.0184)\end{array}$ & $\begin{array}{c}0.2378 \\
(0.0143)\end{array}$ & *** & $\begin{array}{l}0.0939 \\
(0.0384)\end{array}$ & $\begin{array}{c}0.0502 \\
(0.0091)\end{array}$ & *** & $\begin{array}{l}0.0193 \\
(0.0079)\end{array}$ & $\begin{array}{l}0.0059^{* * *} \\
(0.0020)\end{array}$ & $\begin{array}{l}-0.0432^{* * *} \\
(0.0159)\end{array}$ & $\begin{array}{l}-0.0239^{* * *} \\
(0.0058)\end{array}$ & $\begin{array}{l}-0.0177^{* * *} \\
(0.0058)\end{array}$ & $\begin{array}{l}-0.00722^{* *} \\
(0.0033)\end{array}$ \\
\hline $\begin{array}{l}\text { B. Control for immigrant parent's } \\
\text { years of schooling }\end{array}$ & $\begin{array}{l}0.2216 \quad * * * \\
(0.0175)\end{array}$ & $\begin{array}{c}0.2163 \\
(0.0139)\end{array}$ & $* * *$ & $\begin{array}{c}0.0581 \\
(0.0416)\end{array}$ & $\begin{array}{c}0.0021 \\
(0.0149)\end{array}$ & & $\begin{array}{l}0.0187 \\
(0.0096)\end{array}$ & $\begin{array}{c}0.0015 \\
(0.0032)\end{array}$ & $\begin{array}{l}-0.0271 \\
(0.0203)\end{array}$ & $\begin{array}{c}0.0067 \\
(0.0085)\end{array}$ & $\begin{array}{l}-0.0137 \\
(0.0077)\end{array}$ & $\begin{array}{c}0.0028 \\
(0.0064)\end{array}$ \\
\hline C. Control for family income & $\begin{array}{l}0.2301 \\
(0.0189)\end{array}$ & $\begin{array}{c}0.2311 \\
(0.0145)\end{array}$ & *** & $\begin{array}{c}0.0740 \\
(0.0379)\end{array}$ & $\begin{array}{c}0.0398 \\
(0.0075)\end{array}$ & *** & $\begin{array}{l}0.0213^{* * *} \\
(0.0080)\end{array}$ & $\begin{array}{l}0.00511^{* *} \\
(0.0022)\end{array}$ & $\begin{array}{l}-0.03722^{* *} \\
(0.0159)\end{array}$ & $\begin{array}{l}-0.0165^{* * *} \\
(0.0055)\end{array}$ & $\begin{array}{l}-0.0155 * * \\
(0.0063)\end{array}$ & $\begin{array}{l}-0.0035 \\
(0.0044)\end{array}$ \\
\hline $\begin{array}{l}\text { D. Control for whether immigrant } \\
\text { parent worked last year }\end{array}$ & $\begin{array}{l}0.2388 \\
(0.0181)\end{array}$ & $\begin{array}{c}0.2369 \\
(0.0139)\end{array}$ & *** & $\begin{array}{l}0.1002 \\
(0.0367)\end{array}$ & $\begin{array}{c}0.0486 \\
(0.0094)\end{array}$ & *** & $\begin{array}{l}0.0190 \\
(0.0083)\end{array}$ & $\begin{array}{l}0.0061^{* * *} \\
(0.0019)\end{array}$ & $\begin{array}{l}-0.0349 \\
(0.0175)\end{array}$ & $\begin{array}{l}-0.0208^{* * *} \\
(0.0063)\end{array}$ & $\begin{array}{l}-0.0161^{* * *} \\
(0.0058)\end{array}$ & $\begin{array}{l}-0.0064 \\
(0.0037)\end{array}$ \\
\hline E. Control for all of the above & $\begin{array}{l}0.2220 \\
(0.0183)\end{array}$ & $\begin{array}{c}0.2194 \\
(0.0138)\end{array}$ & $* * *$ & $\begin{array}{c}0.0546 \\
(0.0415)\end{array}$ & $\begin{array}{l}-0.0022 \\
(0.0146)\end{array}$ & & $\begin{array}{c}0.0210 \\
(0.0101)\end{array}$ & $\begin{array}{c}0.0016 \\
(0.0031)\end{array}$ & $\begin{array}{l}-0.0177 \\
(0.0224)\end{array}$ & $\begin{array}{c}0.0106 \\
(0.0100)\end{array}$ & $\begin{array}{l}-0.0105 \\
(0.0080)\end{array}$ & $\begin{array}{c}0.0052 \\
(0.0065)\end{array}$ \\
\hline $\begin{array}{l}\text { Difference from base effect } \\
\text { (difference as \% of base effect) }\end{array}$ & $\begin{array}{r}-0.0167 \\
-7 \%\end{array}$ & $\begin{array}{r}-0.0183 \\
-8 \%\end{array}$ & & $\begin{array}{r}-0.0393 \\
-42 \%\end{array}$ & $\begin{array}{r}-0.0525 \\
-104 \%\end{array}$ & & $\begin{array}{r}0.0017 \\
9 \%\end{array}$ & $\begin{array}{r}-0.0043 \\
-73 \%\end{array}$ & $\begin{array}{r}0.0254 \\
-59 \%\end{array}$ & $\begin{array}{c}0.0345 \\
-144 \%\end{array}$ & $\begin{array}{r}0.0072 \\
-41 \%\end{array}$ & $\begin{array}{c}0.0124 \\
-172 \%\end{array}$ \\
\hline
\end{tabular}

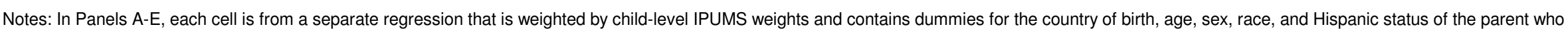

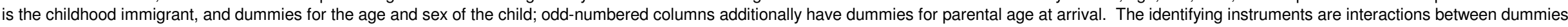
for parental age at arrival and dummy for parent from non-English-speaking country. Robust standard errors adjusted for clustering by parental country of birth are shown in parentheses. Asterisks denote significance levels $\left({ }^{*}=.10,{ }^{* *}=.05,{ }^{* * *}=.01\right)$. 